Published in final edited form as:

Adv Drug Deliv Rev. 2013 December ; 65(15): 2045-2060. doi:10.1016/j.addr.2013.08.001.

\title{
Carbon nanotubes in hyperthermia therapy
}

\author{
Ravi Singh ${ }^{1}$ and Suzy V. Torti ${ }^{2,}$ \\ ${ }^{1}$ Department of Cancer Biology, Wake Forest School of Medicine, Winston Salem NC 27157 \\ ${ }^{2}$ Department of Molecular, Microbial and Structural Biology, University of Connecticut Health \\ Center, Farmington CT 06030
}

\begin{abstract}
Thermal tumor ablation therapies are being developed with a variety of nanomaterials, including single-and multiwalled carbon nanotubes. Carbon nanotubes (CNTs) have attracted interest due to their potential for simultaneous imaging and therapy. In this review, we highlight in vivo applications of carbon nanotube-mediated thermal therapy (CNMTT) and examine the rationale for use of this treatment in recurrent tumors or those resistant to conventional cancer therapies. Additionally, we discuss strategies to localize and enhance the cancer selectivity of this treatment and briefly examine issues relating the toxicity and long term fate of CNTs.
\end{abstract}

\section{Keywords}

photothermal therapy; carbon nanotubes; single-walled nanotubes; multiwalled nanotubes; cancer therapy

\section{Introduction}

Carbon nanotubes (CNTs) consist of one or more seamless, cylindrical graphitic sheets of $\mathrm{sp} 2$ carbon atoms bonded together in an edgeless, hexagonal network [1]. Their combination of electrical, thermal and spectroscopic properties has evoked great interest; biomedical researchers are using CNTs to develop new technologies for the detection, monitoring and therapy of diseases including cancer [2-6]. CNTs can be internalized easily by cells [7-9] and act as delivery vehicles for drugs, nucleic acids, and imaging agents [7, 10-23]. Their unique optical, thermal and cancer selective properties afford the possibility to engineer multiple diagnostic and therapeutic functions into a single particle [2,24]. This makes CNTs extremely suitable for further biomedical development [25].

Minimally invasive, rapidly administered, and highly selective nanotechnology-based thermal tumor ablation therapies are being developed with a variety of nanomaterials (reviewed in [26]). These include single walled carbon nanotubes (SWCNTs) [27], multiwalled carbon nanotubes (MWCNTs) [28], graphene [29], iron oxide nanoparticles [30], gold nanorods [31] and gold nanoshells [32, 33]. Heat-based cancer therapy requires elevation of malignant tissues to supraphysiologic temperatures [34-39]. Exposure to high temperature for a sufficient amount of time causes physical damage such as protein

(C) 2013 Elsevier B.V. All rights reserved.

*To whom correspondence should be addressed: storti@uchc.edu, Phone: 860-679-6503.

Publisher's Disclaimer: This is a PDF file of an unedited manuscript that has been accepted for publication. As a service to our customers we are providing this early version of the manuscript. The manuscript will undergo copyediting, typesetting, and review of the resulting proof before it is published in its final citable form. Please note that during the production process errors may be discovered which could affect the content, and all legal disclaimers that apply to the journal pertain. 
denaturation and membrane lysis and can increase oxidative stress [34, 35, 40, 41]. These effects may be cytotoxic on their own, causing coagulative necrosis or apoptosis[37, 39]. Additionally, hyperthermic treatments that increase temperatures more modestly may enhance the anti-cancer efficacy of ionizing radiation or systemic chemotherapy regimens $[40,42,43]$.

Dose limiting toxicities resulting from diffuse heating of non-tumor tissues and the relative invasiveness of thermal ablative instrumentation have limited wider clinical use of thermal ablation for cancer therapy [44]. However, with recent refinements in technology, the role of such therapies should increase in the near future $[26,45,46]$, and nanotechnology is playing a key role in these advances. Human clinical trials are ongoing for a gold nanoshell based photothermal cancer therapy (Id: NCT00848042 on ClinicalTrials.gov) and for iron oxide nanoparticle-based magnetic thermotherapy [47, 48]. Although the results of these studies are promising, there remains significant room to improve upon both the generation and localization of heat for thermal therapy.

In this arena, CNTs have emerged as promising, next generation agents for thermotherapy of cancer. Currently, significant efforts are being applied to develop CNT-based, clinical treatments. In this review, we will specifically high-light in vivo applications of CNTmediated thermal therapy (CNMTT) and examine the rationale for use of this treatment in recurrent tumors or those resistant to conventional cancer therapies. Additionally, we will identify strategies to localize and enhance the cancer selectivity of this treatment, and briefly examine issues relating the toxicity and long term fate of CNTs.

\section{CNT-mediated thermal therapy: rationale and current status}

Carbon nanotubes offer an exceptional combination of attributes for the development of the next generation of photothermal agents; chief among these is their ability to efficiently convert near infrared radiation (NIR) into heat [49]. Compared to other wavelengths of light, the transmission of NIR through the body is poorly attenuated by biological systems [50, 51]. Penetration of light through tissue is fundamental to photothermal applications of nanomaterials for the treatment of non-superficial cancerous lesions in vivo [28]. Following exposure to NIR, CNTs enter an excited state and release vibrational energy that is transformed into heat, which can induce cell death [27, 52].

CNTs possess an extremely broad electromagnetic absorbance spectrum, covering the full spectras of both the NIR I and II windows [53], which correspond to the "optical transmission window" of biological tissues [50,51], and the radio frequency and microwave bands as well [54]. Further tuning of the photophysical properties of CNTs can be achieved by tailoring the wall number, diameter, and length of the nanotubes according to the "nanoattenna" effect [52]. Critically, NIR absorption and energy transduction efficiency remains high across a wide frequency range [53], which allows for flexibility in the choice of both material characteristics (diameters from $<2 \mathrm{~nm}->30 \mathrm{~nm}$; lengths from $<100 \mathrm{~nm}$ to $>1 \mathrm{um}$ ) and excitation wavelengths. This provides great versatility to tailor size, shape, and surface properties to optimize the tissue distribution of CNTs without a significant loss in thermal conversion efficiency. The broad electromagnetic absorbance spectrum of CNTs also offers a significant advantage over plasmonically heated nanomaterials (such as gold nanoshells and nanorods) for which the excitation spectra are highly dependent upon the size and shape of the particles [2]. While direct comparisons are difficult to make, some estimates indicate that CNTs can achieve thermal destruction of tumors at 10-fold-lower doses and 3-foldlower power than is needed for gold nanorods [53]. However, in contrast to gold nanoparticles, which can be synthesized with great uniformity and have already been tested 
in human clinical trials, production of uniform, well-characterized CNTs remains a significant hurdle for clinical translation.

CNTs exhibit both advantages and limitations in thermal therapy when compared to iron oxide nanoparticles. The magnetic field used to excite iron oxide nanoparticles as a means of generating heat offers superior depth of energy penetration as compared to NIR, but the slower rate of heating induced by this technique leads to significant thermal diffusion away from the targeted area (discussed in section 2.3), potentially increasing collateral damage to neighboring healthy tissue [55]. A second drawback of this technique is that it also requires the removal of all metallic materials within the magnetic field covering the treatment area including dental fillings, crowns and implants. On the other hand, iron oxide nanoparticles, like gold nanoparticles, share a significant advantage over CNTs because uniform preparations of iron-based nanoparticles can be synthesized and have already been tested in human clinical trials.

In most cases, the clinical model for the use of CNTs as heat transduction agents is based upon laser-induced thermotherapy (LITT) [33, 39], a photothermal ablation technique in which an NIR laser is used to heat a target tissue, such as a tumor, above the thermal ablation temperature threshold of approximately $55^{\circ} \mathrm{C}[33,56]$. A major limitation of LITT has been an inability to consistently achieve thermoablative temperatures throughout the target lesion and to confine treatment exclusively to the tumor [57, 58]. Therefore, to be of clinical benefit, CNTs must greatly improve the deposition of heat following NIR exposure without causing any significant toxicity on their own.

\subsection{In vivo anticancer efficacy of CNT-mediated thermal therapy}

The efficacy of CNMTT for the treatment of locoregional tumors in vivo has been demonstrated using syngeneic models of cancer in mice [53, 59], rabbits [54], and in human xenografts grown in mice (reviewed in [49]. In most cases, CNTs are injected systemically or directly into the tumor, which is then exposed to an external NIR (typically a YAG or diode laser) or microwave source. As highlighted in table 1, CNMTT has proven effective for the treatment of a wide variety of cancer types both in vitro and in vivo. In this review, we will focus our discussion upon recent developments in CNMTT treatment of human cancer xenografts in animal models.

Initial in vivo studies of CNMTT focused on the use of SWCNTs, and the results were mixed. Moon et al demonstrated that following intratumoral injection of SWCNTs into mice bearing flank xenografts of human mouth carcinoma cells and NIR irradiation $\left(3 \mathrm{~W} / \mathrm{cm}^{2} ; 3\right.$ $\mathrm{min}$ ), the tumors were completely destroyed [60]. Normal tissue adjacent to the treated area was spared; however, the irradiation procedure itself resulted in significant burning of the heated area even in the absence of SWCNTs. Significantly, no indication of tumor recurrence or apparent side effects of treatment were observed during several months of follow-up [60]. Huang et al achieved more modest results following a similar treatment [59]. Using mice bearing syngeneic murine squamous cell tumors, the researchers intratumorally injected SWCNTs and irradiated the tumor with a low power $\left(200 \mathrm{~mW} / \mathrm{cm}^{2}\right)$ NIR laser for 10 minutes. They observed that treatment resulted in a maximum tumor temperature of approximately $55^{\circ} \mathrm{C}$, indicating that the thermal ablation threshold was reached. However, while a reduction in tumor growth and a modest survival advantage were documented, this treatment failed to achieve a durable cancer remission. In contrast to Moon et al [60], necrotic normal tissue was present adjacent to the treatment site, indicating significant heat transfer away from the targeted site and into the surrounding non-tumor region. As discussed in more detail in section $\mathbf{2 . 3}$, recent work by Xie et al [61] modeling the effects of energy deposition rate on the efficacy of CNMTT suggest that the slower rate of energy deposition used by Huang et al [59] as compared to Moon et al [60] may have resulted in 
greater heat diffusion leading to lesser treatment efficacy and more collateral damage to surrounding tissue.

Following synthesis, SWCNTs are a mixture of metallic and semiconducting SWCNTs. Differences in the density of state at the Fermi level of metallic SWCNTs (which have a finite value $\neq 0$ ) and semiconducting SWCNTs (which have a value of zero) imply that metallic SWNTs more efficiently absorb and convert NIR into heat, and this was recently confirmed by Murakami et al [62]. Consistent with the concept that CNTs with a more metallic nature possess enhanced NIR thermal conversion efficiency, both Burke et al [28] and Ghosh et al [63] reported that MWCNTs, which are inherently more metallic than unpurified SWCNTs, were 20-100 fold more efficient than bulk SWCNTs at conversion of NIR into heat. As shown in figure 1, in vivo studies demonstrated durable remission and long-term survival (> 6 months post-treatment) after intratumoral injection of MWCNTs into tumors implanted in the flanks of nude mice combined with exposure to NIR $\left(3 \mathrm{~W} / \mathrm{cm}^{2}\right.$; $30 \mathrm{sec}$ ) [28]. Significantly, this result was achieved using one-sixth of the energy Moon et al [60]required to achieve a similar result using SWCNTs. Because of this, laser treatment in the absence of MWCNTs resulted in only minimal superficial burning [28]. In the same study, electron microscopy studies revealed that at least a portion of MWCNTs remained intact at the injection site, but no toxicity was detected [28]. Ghosh et al observed similar results for in vivo treatment of tumors using MWCNTs and NIR [63]. Moreover, they confirmed the importance of CNT dispersion on the efficacy of such therapy. By selfassembly, they encased MWCNTs in DNA, which disentangled the tubes. Compared to dispersions of MWCNTs prepared in the absence of DNA, well dispersed DNA encased MWCNTs were more efficient at converting NIR into heat, which led to more effective tumor treatment in mice [63].

As previously noted, CNTs can be heated by externally delivered microwave radiation. Therefore, CNTs may be capable of non-invasively treating tumors in any part of the body, a capability currently not shared by NIR laser-based treatments. In the first study to investigate cancer treatment using an external (non-contacting) microwave source to heat intratumoral SWCNTs, treatment of VX2 hepatocellular carcinoma xenografts in rabbits resulted in complete thermal necrosis of the tumor. No toxicity was seen but there was a 2-5 $\mathrm{mm}$ zone of thermal injury to the surrounding liver [54]. To date, studies on microwave or radiofrequency heating of CNTs for cancer therapy are extremely limited and more research will be needed to determine if this promising strategy is clinically viable.

\subsection{Selective delivery of CNTs to tumors for CNT-mediated thermal therapy}

Fueled by the promise demonstrated by these early studies, researchers are now evaluating strategies to selectively deliver CNTs to tumor sites following systemic administration. One such strategy, known as the enhanced permeation and retention effect (EPR), proposes that increases in tumor accumulation can be achieved by nanoparticles that remain in circulation for long periods due to the nanoparticles' ability to extravasate through the leaky vasculature surrounding the tumor and enter the tumor site [64]. Like many nanoparticles, the blood circulation half-life and tumor accumulation of CNTs can be increased in mice by coating nanoparticles with steric stabilizers such as polyethylene glycol (PEG), which inhibit nanoparticle blood clearance by macrophages and other components of the mononuclear phagocyte system $[10,65-68]$.

Recently, a significant step toward the development of tumor selective, systemically delivered CNTs for photothermal ablation was achieved by Robinson et al [53]. The researchers coated, short (140 nm) SWCNTs with a PEG-funtionalized phospholipid by selfassembly and then injected the CNTs into mice bearing 4T1 murine breast tumors at a dose of $3.6 \mathrm{mg} / \mathrm{kg}$ via the tail vein. Three days later, the inherent NIR photoluminescence of the 
SWCNTs was quantified using an optical imaging system to confirm the accumulation of SWCNTs at the tumor site. Following exposure to NIR $\left(0.6 \mathrm{~W} / \mathrm{cm}^{2} ; 5 \mathrm{~min}\right)$, complete tumor ablation was observed on mice previously administered SWCNTs. These mice survived without recurrence for the duration of the six month study and no toxicity was seen [53].

In another study, Liu et al systematically evaluated the relationship between the length and density of PEGylation on the SWCNT surface and the biodistribution, tumor accumulation and photothermal ablation efficacy of PEG-functionalized SWCNTs injected intravenously into mice [69]. They observed long blood circulation half-lives (16-21 hrs) for heavily PEGylated SWCNTs and high tumor uptake. However, this came at the cost of extensive accumulation of SWCNTs in the mouse skin dermis. They found that by controlling the degree of PEGylation to achieve a blood circulation half-life of 12-13 hrs, they were able to balance high tumor uptake of the SWCNTs with low skin retention. Two days after intravenous injection of the SWCNTs into tumor bearing mice, the researchers exposed the tumors to NIR, achieving a surface temperature of over $50^{\circ} \mathrm{C}$. In contrast, the temperature rise in tumors treated with NIR in the absence of SWCNT injection was only $1-2^{\circ} \mathrm{C}$. Significant reduction in tumor growth was observed in the SWCNTs and NIR treated mice, and three of the seven mice treated exhibited complete regression for the two week study [69]. This study suggests that fine tuning the surface properties of CNTs is critical to enhancing their passive tumor targeting capabilities.

Notably, the intravenously injected nanotubes used by Robinson [53] or Liu [69] were not modified to display a specific targeting ligand, nor is it known if they were they internalized by the cancer cells themselves. Attachment of ligands with an enhanced binding affinity for cancer specific biological moieties is one strategy which may allow for more selective therapy. This can be accomplished by conjugation of peptides, proteins or antibodies to the surface of CNTs, and has been shown to increase the specificity of CNT tumor targeting following intravenous injection in mice [27, 68, 70,71]. Targeting CNTs to cancer cells in vitro using agents including folic acid [72-74], the breast cancer associated receptor Her2 $[75,76]$, and anti-GD2, a monoclonal antibody targeting a carbohydrate antigen overexpressed in neuroblastomas [77] has been shown to increase the specificity and efficacy of CNMTT as compared to non-targeted tubes. Additionally, CNTs can effectively display more than one targeting ligand on their surface which is a strategy that can be used to expand both the tropism and specificity of cancer-targeted CNTs. For example, SWCNTs conjugated to antibodies targeting Her2 and insulin-like growth factor 1 receptor (IGF1R) attached to SWCNTs [78] were shown to be effective at targeting CNMTT to cells expressing one or both of the targeted receptors.

The benefits of actively targeting nanoparticles to tumors in vivo remain the subject of much debate [79], and more research is needed to determine if active targeting will offer an additional benefit for delivery of CNTs. The underlying mechanisms by which CNTs are taken up by cells are still under investigation with both energy-dependent internalization mechanisms (e.g. phagocytosis; clatherin or caveolae mediated endocytosis) and passive diffusion through the plasma membrane (e.g. "nanoneedle" effects) apparently playing a role [9]. As noted above, comparative studies between actively targeted and non-targeted CNTs generally indicate that targeted CNTs are taken up to a greater degree than untargeted tubes. Give the many non-specific mechanisms through which CNTs can bind to and enter cells, precisely how targeting increases the binding and/or uptake of actively targeted CNTs remains to be determined. It is conceivable that the PEG coating commonly used to functionalize the CNT surface may reduce the interaction of coated CNTs with cells; introduction of a binding moiety to the PEGylated CNT would then greatly increase the targeting specificity. To date, direct comparisons of the binding and uptake of PEGylated and uncoated CNTs have not been conducted. Comparative studies of nanoparticle binding 
kinetics are complicated because the physical properties that influence cellular interactions of nanoparticles also affect their solution dynamics [80]. Nanoparticles diffuse, settle and agglomerate in cell culture media as a function of systemic and particle properties (e.g. media density and viscosity, particle size, shape and density). Therefore the delivered dose of nanoparticles in cell culture is a function not only of cell binding and uptake pathways, but of the rate of transport in solution as well. To date, most studies using targeted CNTs fail to account for changes in solution dynamics induced by structural alterations in the CNTs caused by the addition of targeting ligands, and further research will be needed to thoroughly understand how such alterations influence binding specificity. Nevertheless, there is strong evidence that internalization of CNTs prior to exposure to NIR can improve the treatment efficacy of CNMTT [75]. For example, Zhou et al demonstrated SWCNTs coated with a phospholipid-PEG conjugate selectively accumulate intracellularly at the mitochondrial membrane [81]. Their proximity to mitochodria allowed for selective destruction of these organelles following NIR exposure, inducing mitochondrial depolarization, cytochrome $c$ release, and caspase 3 activation. Treatment of murine breast cancer tumors in vivo with these modified SWCNTs reduced tumor growth and induced complete tumor regression in some mice [82].

\subsection{Efficacy of CNMTT for treatment of resistant or recurrent cancers}

Thermal ablation therapies based upon CNTs are being tested for the treatment of cancers that are highly resistant to current therapies, including stem-cell like cancer sub-populations $[83,84]$. In many types of tumors, cancer stem cells (CSCs) have been putatively identified as self-renewing, therapy-resistant populations [85].

In glioblastomas and other brain tumors, the CD133 receptor appears to be a CSC marker associated with malignancy, tumor recurrence, and poor survival. [86-88]. CD133+ subpopulations in glioblastoma are enriched following radiotherapy, are radio and chemotherapy resistant, and may be responsible for tumor recurrence following treatment $[86,89,90]$. Treatment strategies based on targeting this subpopulation may prevent the development of resistance to therapy. To test this hypothesis, Wang et al conjugated a monoclonal antibody directed against CD133 to MWCNTs [83]. They observed specific internalization of these targeted MWCNTs in primary clinical isolates of glioblastoma that expressed CD133, but not in cells which did not. To determine the in vivo efficacy of this treatment, CD133 expressing glioblastoma cells were pre-treated with targeted MWCNTs before inoculation into mice. The cells took up the MWCNTs, and xenograft growth was abolished after NIR exposure. This key study demonstrated the potential for CNTs to treat glioblastomas and other currently untreatable cancers.

Another recent report describes a novel application of the CNMTT technique to target invasive CSCs in systemic blood circulation [91]. In this study, Galanzha, et al. used the photoacoustic (PA) and photothermal (PT) properties of CNTs for the detection and elimination of circulating CSCs, which are thought to be the primary drivers of metastatic tumor spread [91]. The development of technology to purge these cells from the vasculature of cancer patients could reduce the incidence of metastatic disease. To accomplish this, the researchers constructed NIR-absorbing, gold plated SWCNTs and conjugated them to antihuman CD44 antibodies. These particles selectively labeled circulating human breast CSCs (which overexpress CD44 [92]) in the blood stream. Rare CD44+ circulating cancer stem cells binding nanoparticles were identified in the vasculature of nude mice which bore human breast cancer xenografts by detection of photoacoustic waves generated by excitation of the nanoparticle-labeled cancer cells using a low powered laser [91]. Furthermore, these cells could be ablated following more extended irradiance with NIR [91]. 
Importantly, CNTs may be superior to other heat delivery modalities in ablating cancer stem cells. Burke and co-authors compared the response of breast cancer stem cells (BCSCs) to both conventional hyperthermia and CNMTT to determine the relative therapeutic efficacy of each approach for the treatment of these cancer cells [84]. Key results of this study are shown in figure 2. Notably, BCSCs exhibited high basal expression levels of heat shock protein 90 (HSP 90) which contributed to their ability to tolerate conventional hyperthermia treatments (modeled by water bath heating) that were lethal to non-stem breast cancer cells [84]. BCSCs were found to be resistant to hyperthermia across a range of temperatures, and heat treatments did not reduce the long-term proliferative capacity of these cells. A significant enrichment of BCSCs was detected in the surviving fraction of a mixed population of stem and non-stem breast cancer cells treated with conventional hyperthermia. In contrast, the researchers were able to overcome the resistance to hyperthermia observed in BCSCs through the use of CNMTT. Furthermore, BCSCs that survived CNMTT did not retain long-term proliferative capabilities. The researchers generated precise temperature increases in mixed or isolated populations of BCSCs and non-stem breast cancer cells by exposing the cells to MWCNTs followed by NIR irradiation, which resulted in cell death that was proportional to laser exposure time. In vivo treatment by CNMTT induced complete regression of BCSC-driven tumors in mice for the duration of the 30 day study. In contrast, control groups exhibited $>80 \%$ mortality at identical time points. Based on these findings, CNMTT may represent a rapid, minimally invasive approach for the simultaneous elimination of both the bulk breast tumor and the BCSC components of tumors and represents a significant therapeutic advance for the treatment of refractory, stem cell-driven cancers [84].

Flow cytometric characterization of the cells following treatment indicated that CNMTT, but not conventional hyperthermia, led to rapid membrane permeabilization and necrotic death in treated cancer cells [84]. The high surface temperature of NIR-stimulated MWCNTs [93] may irreversibly permeabilize cell membranes [94, 95], leading to the rapid cytolysis observed in CNMTT-treated cells. Therapies that preferentially cause necrotic death may be therapeutically advantageous by bypassing resistance mechanisms to apoptotic cell death because they do not provide selective pressure toward the emergence of treatment resistant cancer cell clones [96, 97]. The significance of this for CNMTT is exemplified by the fact that elevated HSP90 in BCSCs conferred at least partial protection to classical hyperthermic cell death, but did not protect BCSCs from nanotube-mediated hyperthermic death [84]. Fisher et al also indicated that CNMTT leads to a necrotic rather than apoptotic cell death mechanism [98]. Nevertheless, necrosis has not been universally observed following treatment with NIR and MWCNTs [99], and to date, extensive research has not been conducted to determine factors that may influence the mechanism(s) of cell death induced by CNMTT.

\subsection{Enhancement of conventional cancer therapy by CNMTT}

Hyperthermia synergistically enhances tumor cell cytotoxicity when combined with chemotherapy or radiotherapy, in part by increasing the permeability of tumor vasculature, which can enhance the delivery of drugs into tumors [41]. Thus, in addition to ablation of cancer cells, the thermal effects generated by CNMTT may enhance the efficacy of other therapies. Such strategies may enable the development of therapeutic agents with increased cancer selectivity, reduce the dose necessary for efficacy, decrease the toxicity of such treatments, and thus increase their therapeutic index.

For example, NIR irradiation of MWCNTs to sublethally heat cancer cells increased the uptake of co-delivered chemotherapeutic drugs and enhanced cancer cell death both in vitro and in vivo in a murine ascites tumor model [100]. Excitation of CNTs by exposure to an appropriately tuned radio frequency field has been shown to permeabilize cell membranes to 
allow cell uptake of normally impermeable drugs or gene expression vectors both in in vitro and in vivo in brain tissue [101]. Similarly, treatment of cancer cells or tumor bearing mice using SWNTs chemically conjugated with platinum-based chemotherapeutics [102] or loaded with doxorubicin by hydrophobic interactions [103] and combined with NIR mediated photothermal heating were significantly more effective than either therapy alone. Dual mode carbon nanomaterials have been developed to allow excitation by a single wavelength of light to initiate both photothermal and photodynamic events, allowing for simultaneous generation of therapeutic heat and reactive oxygen species $[62,104]$.

Conjugation of antigens to the surface of CNTs may enhance immune responses by increasing the uptake of such antigens by dendritic cells and macrophages [105]. Recently, the combination of an immunologically modified nanotube and CNMTT was shown to generate a sustained anti-tumor immune response in mice following treatment [106]. Glycated chitosan (GC), an immunoadjuvant, was used as a surfactant to disperse SWCNTs. BALB/c mice bearing syngeneic EMT6 flank tumors were injected intratumorally with GC coated SWCNTs (SWCNT-GC) then exposed to a $980 \mathrm{~nm}$ laser $(0.75 \mathrm{~W} / \mathrm{cm} 2$ for $10 \mathrm{~min})$. All mice treated with the combination of laser and SWNT-GC survived for at least 100 days following treatment. In contrast, only $43.75 \%$ of mice treated with laser and SWNTs without GC, $25 \%$ of mice treated with laser and GC without SWCNTs, and $12.5 \%$ of mice in the laser only group survived. Importantly, mice that were successfully treated by the combination of laser irradiation and SWNT-GC did not develop tumors following rechallenge with EMT6 cells100 days after the initial tumor inoculation. This study shows the combination of laser irradiation and immunologically modified nanotubes can induce systemic antitumor response through a local intervention, with few adverse side effects [106].

\subsection{Beyond cancer therapy: novel applications of photothermal properties of CNTs}

Although most studies have focused on anti-tumor applications of CNMTT, additional applications have also been proposed. Kosuge et al. recently investigated the use of SWNTmediated photothermal ablation of inflammatory macrophages in a mouse model of athlerosclerosis [107]. Following the creation of macrophage-rich atherosclerotic lesions in the carotid arteries, mice were injected with fluorescently tagged SWNTs, which accumulated in the macrophages. Excision of the arteries and ex-vivo illumination with NIR induced heating and apoptosis selectively in SWNT-containing macrophages, providing a proof of principle demonstration that the photothermal properties of CNTs may be useful in treatment of vascular inflammation. Another group used laser excitation of carbon nanohorns to induce expression of genes driven by a heat shock protein- responsive promoter in living mice [108]. The use of NIR-activated SWNTS for 'remote control' of gene expression in living animals may represent both a powerful experimental tool and a new therapeutic venue. Similarly, a recent report indicates that CNTs also may be useful for the development of implantable bioelectronic devices operated by laser irradiation from outside the body [109]. In this study, a unique CNT-based photothermal-electrical (PTE) converter is described. This device is able to convert the thermal energy generated by NIR irradiated with NIR light and convert it to electrical power. Devices powered by this system could be implanted beneath the skin and activated by laser irradiation, providing a new opportunity for biomechanical development or possibly for a remotely activated drug delivery system.

\section{Clinical translation of CNMTT: accomplishments and challenges}

As described above, proof of principle studies in animals have established that CNMTT can address several limitations of contemporary clinical thermal ablation methodologies: (1) the procedure is minimally-invasive, potentially expanding the type and location of tumors that 
can be treated; (2) because each nanoparticle generates heat in response to stimulation electromagnetic radiation, a uniform temperature distribution can be generated throughout the tumor mass; and (3) the heated region is defined by both the location of the CNTs and the position of the irradiation source, confining treatment to the intended lesion and diminishing off-target toxicities. However, as described in the following sections, significant hurdles still must be addressed before CMNTT will be a clinically viable modality.

\subsection{Intratumoral dissemination of CNTs}

Delivery of CNTs and other engineered nanoparticles across large $(>1 \mathrm{~cm})$ tumors represents a major, under-investigated need for biomedical use of nanomaterials [110-116]. As highlighted in figure 3, multiple inter-related properties influence particle distribution; these are dependent not only on the characteristics of the particular type of CNT, but also upon the environment in which the particle is to be used and the strategy by which it will be delivered. As more information on the use of CNTs in animal models becomes available, it is clear that like other nanoparticles, even minor structural or chemical changes to the particle surface significantly alter the biodistribution of CNTs [117].

The in vivo intratumoral distribution of CNTs largely is related to the physicochemical properties of the tubes, which include length, diameter, degree of agglomeration, surface chemistry, and flexibility [25]. The interactions of these properties with the pathophysiology and anatomy of the target site will dictate the biological interactions of the CNTs [118]. Furthermore, it is important to realize that small molecules and proteins frequently adsorb onto the surface of nanoparticles, creating an interface at which all further interactions occur. The environment obviously influences the composition of this interface, and creates an additional factor that is rarely taken into account when evaluating the efficacy and distribution of CNT preparations.

Current delivery strategies, which are limited to either intravenous injection or direct intratumoral injection do not address the issue of limited macromolecular diffusion of CNTs once they enter the tumor microenvironment. Recent work suggests that this may be an issue of considerable complexity [119]. Using intravital microscopy, the authors demonstrated that SWNTs and spherical particles with similar surface coating, area, and charge nevertheless exhibit different abilities to extravasate into tumors. Rather remarkably, the relative penetrance of these particles was dependent on tumor type: spherical particles preferentially extravasated into LS174T colon tumors, whereas SWNTs accumulated preferentially into U87MG gliobastoma tumors; neither particle extravasated into SKOV-3 ovarian adenocarcinoma tumors. The mechanistic basis for this difference remains to be determined, but these results suggest that biological characteristics of the tumor itself will be an important determinant in the optimization of therapeutic nanoparticles.

Among the options for enhancing intratumoral dissemination, a dense PEG coating is known to improve penetration of large nanoparticles in tissue [120], but the role of PEG coating on CNT diffusion in tumors has not yet been assessed. Furthermore, pressure-driven infusion techniques such as convection enhanced delivery (CED), which rely on a pressure gradient rather than diffusion to distribute macromolecules, may be of benefit. CED of nanomaterials is an area of current research [121] but has not yet been tested for the delivery of CNTs. Positive indications for use of CED for CNTs include: (1) CNTs can be synthesized with diameters $(<30 \mathrm{~nm})$ far smaller than the estimated pore size in the extracellular matrix (ECM) of many tumors $[112,122,123]$; (2) CNTs tend to align parallel to the direction of fluid flow [124]; and (3) their diffusion can be enhanced by selectively tuning their surfaces to the physical properties of porous media [119, 125-128] like the ECM. 
More research is needed to identify specific properties or strategies that will enhance intratumoral transport of CNTs both during and after infusion. It will be particularly important to these studies that CNTs for use in biomedical applications have well-defined preparation chemistries combined with rigorous physicochemical characterization, and, as discussed below, that their in vivo performance can be tracked by non-invasive imaging techniques.

\subsection{Monitoring intratumoral distribution of CNTs}

For the clinical application of CNMTT for cancer treatment, CNTs must be specifically engineered to be compatible with an imaging modality to spatially define the margins of the target lesion, assess the distribution of injected CNTs within the tumor, and to allow for placement of the electromagnetic radiation source. The versatility of CNTs as a platform technology has seen the development of CNT-based imaging agents for use as magnetic resonance imaging (MRI) contrast enhancers[22, 129-132], positron and single photon emission correlation spectroscopy (PET/SPECT) [19, 70, 133, 134], fluorescence imaging $[71,129,135]$ and photoaccoustic and Raman imaging [136]. Carbon nanotubes offer several advantages for targeted molecular imaging techniques, including their ability to deliver large numbers of imaging agents per each targeted molecular recognition, which can improve the sensitivity of imaging, and their ability to simultaneously display several different types of agents to perform multimodality imaging.

A unique feature of SWCNTs is that they possess an intrinsic fluorescence in the second near-infrared window (NIR II, 1.1-1.4 $\mu \mathrm{m}$ ) upon excitation by laser emission in the traditional near-infrared region (NIR I, 0.75-0.9 $\mu \mathrm{m}$ ) [137]. Compared to the NIR I window, the longer wavelength emission in NIR II offers great promise for the development of SWCNT imaging agents due to minimal autofluorescence and tissue scattering, which allows for deeper anatomical penetration and greater spatial resolution than is currently available for traditional NIR imaging agents [137]. Studies by Welsher et al indicate the SWCNT-based fluorophores can be imaged deep inside mice following excitation with a modest laser power [135]. Similarly, injection of SWCNTs into the blood allows for quantifications of blood velocity and mapping of small vessels which an accuracy that is far beyond the capabilities of ultrasonography [137]. Initial studies show that intravenously injected SWNTs could be used as as photoluminescent agents for in vivo tumor imaging in the 1.0-1.4 $\mu \mathrm{m}$ emission region and as NIR absorbers and heaters at $808 \mathrm{~nm}$ for photothermal cancer therapy [53]. Additional clinical applications of these tubes potentially could include contrast enhancement for delineation of tumors/metastasis, or for mapping intratumoral vasculature.

Several additional studies have examined dual modality CNTs for both imaging and photothermal applications. In one study, Ding et al constructed MWCNTs containing increasing amounts of ferrocene, an iron-based catalyst used in the production of CNTs [22]. These iron-containing MWCNTs were studied for their potential use as dual modality agents for both MR contrast enhancement and photothermal energy transduction. The researchers demonstrated that iron-containing MWCNTs were effective MR contrast agents. In vivo MR imaging provided a clear indication of intratumoral distribution of the CNTs, allowing for image guided intervention. Following multiple rounds of NIR exposure, the contrast enhancing and heating properties of the MWCNTs did not change, even after reaching thermal ablative temperatures [22]. When injected into tumor bearing mice, the ironcontaining MWCNTs could be detected at the injection site before and during heating, and until the end of the study one week later [22]. An additional advantage conferred by this imaging strategy was the ability to monitor temperature in real time using MR thermometry (see section 2.3). Conceptually, this demonstrates that multiple or fractionated laser 
treatments could be targeted to the tumor without the need for additional injections, and the distribution of the MWCNTs could be monitored over time.

In addition to MR imaging, photoacoustic molecular imaging using CNTs has shown some early promise [138]. Photoaccoustic imaging relies upon detection of the shock wave that is generated following heating of the CNTs by an external NIR source. Recent studies by Zhou and colleagues indicate that CNTs targeted to av $\beta 3$ integrin could be designed to possess both high photoaccoustic contrast and and efficient targeting of av $\beta 3$ integrin positive U87 human glioblastoma tumors in mice, suggesting that photoacoustic molecular imaging with targeted SWNTs has the potential for use as a tumor diagnostic method [138]. In another study, Zarov and colleagues developed golden carbon nanotubes (GNTs) consisting of SWCNTs encased in gold layers [139]. The gold coating not only enhanced the photothermal transduction efficiency of the tubes, it introduced a high plasmon resonance at 850-900 nm, indicating the the GNTs could be used for both non-invasive photoaccoustic (PA) imaging and photothermal cancer therapy [140]. Moreover, cancer diagnosis and therapy applications using these tubes could be performed with the same laser in real time using a unique in vivo flow cytometry based imaging system [139]. Using anti-CD44 labeled GNTs, the researchers were able to detect single CD44+ circulating breast cancer stem cells in the blood stream of tumor bearing mice following NIR irradiation. They postulate that these cells could be eliminated by increasing the laser power [139].

From these studies, it is clear that CNTs can be developed for both cancer imaging and effective photothermal therapy and are compatible with current imaging technologies. Future developments of such agents would have a dramatic effect on non-invasive cancer diagnosis, targeted therapies, selection of patient specific treatments, and monitoring of cancer progression or recurrence.

\subsection{Optimizing heat localization and treatment efficacy of CNMTT}

Heat delivery for photothermal applications is dependent upon the total laser energy incident upon the target and the efficiency of the target at converting that energy into heat. Temperature elevation by CNMTT is limited by the maximum laser output, penetration of the light, the CNT concentration in the tumor target, and heat dissipation away from the tumor target. Heat dissipation away from the tumor target is a complex process that is dependent upon environmental factors including proximity to heat absorbers (i.e. blood vessels and neighboring normal tissue), solvent, and the substrate (tissue type) into which the CNTs are dispersed. This process is dynamic, making it essential to develop strategies to reproducibly control the spatial and temporal distribution of heat used to ablate tumors [141].

To reduce off-target damage due to thermal diffusion, the total energy deposited into the tissue should be minimized such that only the amount of heat needed for treatment is delivered to the targeted area. To accomplish this, it is necessary to monitor in real-time spatio-temporal changes in temperature resulting from CNMTT using infrared cameras [59, 141] or magnetic resonance imaging (MRI)-based methods [28, 61]. Infrared cameras are useful for optimizing both CNT concentration and NIR irradiation parameters in model tissue and in tumor bearing mice, but cannot accurately map temperature deep within tissue. However, a more clinically relevant method of non-invasive temperature mapping is a MRIbased thermometry method known as proton resonance frequency (PRF) MR temperature mapping (reviewed in [142]). This technique allows for superposition of both temperature information and anatomical images at any depth, and is currently used clinically to monitor the efficacy of thermal ablation techniques. By relating the treatment temperature to actual thermal tissue damage, PRF MR temperature mapping can be useful in predicting the treatment outcome [61]. 
Extensive work by Torti and colleagues has demonstrated the compatibility of PRF MR temperature mapping with CNMTT [22, 28, 61]. For example, Burke et al used PRF MR temperature maps to measure the temperature increase in kidney tumor xenografts following CNMTT [28]. Use of MRI contrast enhancing CNTs allows for monitoring of nanomaterial distribution [22] in the tumor and can aid in placement of the NIR source [143]. Ding et al showed that iron-containing MWCNTs act as dual mode MRI T2 contrast agents and photothermal mediators [22]. However, a potential limitation of iron-containing MWCNTs is their propensity to attenuate MR signals, which can interfere with temperature mapping by PRF MR thermometry [22].

Though dependent upon tumor type and location, generation of sufficiently high temperatures to ablate large $(>3 \mathrm{~cm})$ tumors while minimizing damage to healthy tissue surrounding the tumor due to heat delocalization is the major limitation to all current approaches to thermal ablation therapy [144]. Experimental use of nanosecond pulsed lasers has been successfully applied to localize heat on the cancer cell level in the presence or absence of CNTs [144-147]. However, use of continuous irradiation for tenths of seconds or longer (rather than nanosecond pulses) to heat a large number of nanoparticles dispersed throughout a tumor produces an overall temperature rise several orders of magnitude larger than the localized (nanoscale) temperature rise near each particle [141, 148]. Recently, Xie et al used a combination of experimental data in tissue phantoms and diffusive heat modeling to determine the thermal distribution CNT-bearing tumors during and following NIR irradiation and used clinically relevant damage predicting algorithms to quantify the likely efficacy of CNMTT following treatment with different laser pulse strengths and durations (summarized in figure 4). Fitting of the data to diffusive heat models indicates that it may be possible to achieve thermally ablative temperatures within in sharply defined regions ( $<1 \mathrm{~mm}$ margins) in as little as 2 seconds using clinically available continuous NIR lasers in combination with modest CNT concentrations [61]. In this short time scale, heat deposition is more rapid than thermal diffusion and convective cooling, which will simplify treatment planning and reduce heat diffusion to surrounding normal tissue as compared to current clinical thermal ablation techniques which require tissue to be heated for up to several minutes to achieve ablative temperatures.

More extended NIR treatment exposure may be necessary for treating bulky tumors because the generated heat can effectively spread over centimeter size regions [61, 141]. Moreover, modeling and experimental data in breast cancer tissue phantoms have shown that the presence of CNTs can extend the effective treatment volume for a fixed NIR energy input $[149,150]$. Burke et al made similar observations in vivo using the induction of heat shock proteins (HSPs) 27, 70, and 90 as endogenous cellular markers of thermal stress for indirect measurement of heat generation in full-depth tissue sections taken from tumors of mice after NIR exposure [28]. In tumors treated with NIR plus MWCNTs, HSPs were seen at deeper tissue levels than in mice treated only with NIR, confirming that CNTs combined with NIR can be used to extend the effective volume of thermal therapy.

There remain several areas, summarized in figure 5, for further study. The temperature distribution following CNMTT is determined by the rate of energy input and efficiency of NIR conversion to heat, which is influenced by concentration [28], aggregation [63], length [52] and wall number of the CNTs [63]. Therefore, careful matching of both CNT type and distribution with NIR irradiation parameters can more effectively treat targeted cell populations. It is not clear how intratumoral distribution of CNTs will affect the efficacy of CNMTT. A homogeneous distribution of CNTs throughout the tumor mass may allow generation of a more predictable and uniform temperature in the targeted area following laser irradiation. However, the effective tissue penetration depth of NIR may be far smaller than the tumor volume to be treated, and thus a more modest distribution of CNTs may be 
needed. Additionally, a better understanding of the contribution of heat dissipation caused by the presence of blood and body fluids will be required to determine both the optimal concentration of CNTs and NIR irradiation parameters required for clinical applications. Finally, a greater understanding of how different cancer cell populations respond to CNMTT -- including heat resistant stem-like cells and tumor cells that have received prior treatment -- may greatly assist in the development of new therapeutic strategies for non-resectable tumors that are resistant to current therapeutic modalities.

\subsection{CNT toxicity and long-term fate}

Progress towards the clinical use of CNTs has been limited in part due to the lack of a comprehensive understanding of the basic determinants of CNT toxicity and clearance from the human body. Fear of exposure to CNTs has been exacerbated because CNTs can act as 'nano-needles', easily piercing cell membranes [8,9], traversing to the nucleus [23] and potentially inducing genotoxicity [151]. One preliminary study on the toxicity of CNTs indicated that when they are injected into the abdominal cavity or lungs of mice, they can induce inflammatory responses and granuloma formation similar to those associated with asbestos exposure [152, 153]; a more recent study further demonstrated mesothelial cell injury and formation of mesotheliomas following peritoneal injection of pristine CNTs [154]. In contrast, a two year study on the potential carcinogenic nature of CNTs injected into the peritoneal cavity of rats found no evidence of CNTs causing cancer [155]. In light of these conflicting results, the future outlook for biomedical application of CNTs continues to be met with scepticism. Fears over CNT exposure increased due to the perception that they were not degraded in the body, though now it is known that some types of CNTs can be degraded in biological systems by oxidative enzymes [156,157]. The persistence of these concerns indicates that for biomedical use of CNTs to progress, the toxicity, and therefore the potential risk-benefit balance for these materials, must be resolved.

Use of CNTs in cancer therapy requires bypassing the body's natural defenses, generating concern that toxicities not previously observed might be induced. However, many strategies have evolved to reduce the toxic effects of CNTs by altering lengths, diameters, or chemically modifying their surfaces [158]. Biomedical use of CNTs requires modification of the highly hydrophobic surface of the tubes to render them hydrophilic [159], but not all chemical treatments alleviate the toxicity risks associated with CNTs. It is essential to identify which characteristics CNTs should possess to be "safe-for-use". It is becoming clear that modifications that render carbon nanotubes short $(<1000 \mathrm{~nm})$, flexible and permit stable suspension in biological fluids are necessary to ameliorate the risks identified for exposure to pristine (unmodified) CNTs [160].

For example, work by Donaldson and colleagues established that the inflammation and fibrosis induced by CNTs introduced into the pleural cavity of mice could be reduced by shortening the length of CNTs [161]. Shorter tubes $(<1000 \mathrm{~nm})$ were not retained in the pleural cavity and eventually were excreted. In another related study, Ali-Boucetta et al described two different chemical modifications to CNT surfaces and asked if either could reduce the inflammatory toxicity of the CNTs following intraperitoneal injection of the tubes [160]. They found that CNTs functionalized using the 1,3-dipolar cycloaddition of azomethine ylides first described by Prato and colleagues [23] to introduce pyrrolidine rings bearing an ammonium-terminated tri(ethylene glycol) chain to the side wall of CNTs do not induce inflammation. In contrast, CNTs functionalized using the method of Billups et al [162] to introduce an octyl chain on the side walls induce an inflammatory response comparable to that observed for long, pristine CNTs [163]. Functionalization of CNTs using the 1,3-dipolar cycloaddition method shortened and debundled the tubes following aqueous dispersion while CNTs functionalized by the Billups method remained aggregated in aqueous suspension [160]. The authors suggest that not all chemical treatments will alleviate 
the toxicity risks associated with CNTs; only chemical reactions to CNT surfaces that lead to CNT shortening and aid in disentangling/debundling of CNTs following aqueous dispersion will reduce the risks [160].

In addition to length and dispersibility in aqueous solvents, a third critical factor which determines the potential of CNTs to cause cell injury appears to be CNT diameter. In a recent study, pristine MWCNTs of differing thickness were suspended in saline solution containing albumin, and their uptake by mesothelial cells was compared to that of asbestos fibers [154]. Mesothelial cells were shown to take up MWCNTs and asbestos by two distinct mechanisms: MWCNTs directly pierced mesothelial plasma and nuclear membranes, whereas asbestos fibers were internalized by endocytosis. Consistent with the observation that the force needed to penetrate cell membranes is proportional to CNT diameter [164], thick MWCNTs (150 nm diameter) were less likely to pierce mesothelial cells than thin MWCNTs (50 nm diameter) [154] . In contrast, asbestos fibers, even those thicker than 150 $\mathrm{nm}$, were easily internalized by the cells because they do not necessarily enter mesothelial cells in the same way as CNTs. This work suggests that not only should CNT toxicology be evaluated differently than asbestos toxicology, but also that control of the diameter of MWCNTs could reduce the potential for mesothelial injury and other hazards caused by CNTs.

The potential risks due to inflammatory responses caused by chronic exposure to CNTs in different tissue are compounded by the possibility of acute risks associated with blood-borne delivery of CNTs [165-168]. Despite the fact that no long-term, or chronic toxicity has been exhibited by mice injected with CNTs that have been chemically functionalized to improve aqueous dispersion $[6,67,133,169-171]$, concerns have persisted regarding the potential thrombogenic nature of CNTs. In this regard, several groups have shown that CNTs have a high propensity to activate elements of the coagulation cascade in vitro [166, 167, 172].

However, in an extensive study comparing the role played by chemical functionalization of CNTs on blood toxicity in vitro to indicators of thrombosis following intravenous injection into mice (platelet counts; D-dimer levels; murine Von Willebrand factor; histology), Burke et al found that in vitro analysis of CNT induced coagulation was a poor predictor of actual in vivo outcomes [173]. Specifically, the researchers found that pristine MWCNTs appeared to be less thrombogenic than chemically functionalized MWCNT (acid oxidized; acid oxidized then amidated) in vitro as indicated by activation of the coagulation cascade, coagulation time, and platelet activation, which is consistent with other recent reports [174]. However, following intravenous injection in mice, pristine MWCNTs were found to rapidly deplete platelets, and induce elevated D-dimer and Von Willebrand factor levels, indicating severe thrombosis, disseminated intravascular coagulation, and endothelial cell injury [173]. At a dose of $250 \mu \mathrm{g}$, pristine MWCNT were acutely lethal, inducing blockage of the pulmonary vasculature. In contrast, the sole measurable effect of an equivalent dose of the two types of functionalized MWCNTs was a transient depletion of platelets [173]. Although more detailed studies must be undertaken before the toxicity profile of CNTs is fully understood, these results support the hypothesis that CNTs can be designed to be suitable for systemic delivery.

Importantly, chemical functionalization of CNTs is also known to greatly influence their blood clearance profile. Following early debates regarding whether the primary clearance route for intravenously administered CNTs was via renal or biliary pathways [133, 175, 176], it is now known that the type and degree of chemical functionalization, degree of agglomeration, and length of the tubes determine the tissue distribution and excretion of CNTs [177-179]. Renal clearance of CNTs in particular has caused much debate as many believe that $5 \mathrm{~nm}$ is the maximum diameter that permits for clearance of nanoparticles via the urine [180]. However, several groups have shown that intact CNTs as long as $500 \mathrm{~nm}$ 
with diameters of up to 25-30 nms can exit the blood stream and be excreted in urine by orienting themselves along their smaller axis to pass through the fenestrated endothelium of the glomerular capillary wall, across the glomerular basement membrane, and through the filtration slits $[133,134,179,181]$ despite these openings being approximately $43 \mathrm{~nm}$ in diameter [182]. A more recent study by Kostarelos et al convincingly confirms these previous works, showing: 1) individualization of CNTs resulting from a high degree of chemical functionalization to introduce hydrophilic groups to the CNT surface aids in rapid renal clearance and low tissue retention; 2) shorter CNTs exhibit greater renal clearance than longer CNTs; and 3) in general, increasing hydrophilic chemically functionalization is associated with renal clearance while decreasing functionalization favors clearance by the mononuclear phagocyte system [177].

Combined, the studies described above indicate that it should be possible to engineer CNTs suitable for future use in humans. New strategies to synthesize and modify CNTs in a highly controlled manner continue to evolve and show tremendous potential for designing CNTs with optimal in vivo characteristics. As more research evaluating the relationship between CNT characteristics and in vivo kinetics, excretion, and toxicity emerges, the clinical use of CNTs is becoming more and more feasible.

\section{Conclusions}

The translation of carbon nanotubes from an interesting nanomaterial to an effective cancer therapeutic agent is an actively evolving field [25]. As discussed in section 1 of this review, CNTs offer enormous possibilities for the development of the next generation of cancer therapeutic and diagnostic agents. Their desirable features include the following: 1) they efficiently convert incident NIR into heat for use in cancer thermal ablation or imaging; 2) they can be used for additional therapeutic applications including chemotherapeutic drug or gene delivery; 3 ) their high surface area to volume ratio per particle allows for incorporation of a high density of imaging agents which can improve the sensitivity of imaging; 4) they can simultaneously deliver several different types of agents to perform multimodality imaging and cancer therapy; 5) they easily cross cell membranes and can be engineered to be exhibit a positive biocompatibility profile.

As research in this field has advanced, a number of issues in the use of CNTs for CNMTT, identified in section 2 in this review, remain to be addressed. Size of the tumor is one consideration. Many cancers do not present until tumors are significantly larger than one or several centimeters in diameter, which is larger than most tumors treated in animal models to date. Delivery of both CNTs and therapeutic heat across these larger tumors represents a major challenge in the pre-clinical development of CNMTT. Most applications to date have relied on NIR, which has a finite range of tissue penetration. Although biological tissues are relatively transparent to NIR, treatment of deep-seated tumors may require either the use of $\mathrm{RF}$ or longer wavelength electromagnetic radiation; such strategies are being actively pursued $[54,183]$. Alternatively, the development of companion technology, such as fiber optic probes that can deliver NIR to the target site, may enable the utilization of NIR for thermal activation of CNTs in even deep-seated tumors. Additionally, strategies must be developed to monitor both the distribution of the CNTs and the deposition, localization, and efficacy of heat treatment.

Conversely, it is also desirable to treat small micrometastases. Currently, CNMTT relies on conventional clinical imaging to detect and localize tumors prior to treatment, and tumors that are too small to be visualized by such methodology will remain untreated. Use of targeted nanoparticles conjugated to imaging moieties may overcome this limitation by allowing the detection and treatment of such small tumors. Targeted nanotubes may also 
permit dose reduction, since each nanotube would have a higher probability of associating with its tumor target. Of particular interest would be the development of CNT-based PET agents, which would allow for extremely high detection sensitivity and depth of penetration. Because the risk of nanoparticle toxicity will go down with decreased exposure, the use of PET as an imaging modality may further push the envelope on clinical development of CNT-based therapeutic and diagnostic agents. A number of potential agents have been tested in mice $[19,70,133,134]$, but their utility in cancer diagnosis has yet to be evaluated.

Most importantly, the long term fate and toxicity of CNTs must be determined. It has become clear that specifics matter: that each change in particle design creates an entirely new particle with novel toxicological, pharmacological and therapeutic properties. This necessitates that both the biomedical and toxicological investigations of these materials take place simultaneously. The debate over toxicity of CNTs continues despite research showing that appropriate design can ameliorate many unwanted effects of CNTs; thus, overcoming the perceived and real potential toxicities of nanotubes may represent the largest hurdle towards their clinical application. Based upon the current evidence, a series of guidelines for future development of CNT-based therapeutics has been proposed by Kostarelos and colleagues [183]. Briefly summarized, these recommendations are: (1) use aqueous preparations of small, hydrophilic, well dispersed CNTs that can easily be internalized by target cells and that macrophages can efficiently take-up and clear after the therapeutic effect is achieved; (2) use colloidal dispersions of CNTs that are stable under physiologic $\mathrm{pH}$ and salinity to minimize aggregation in vivo; and (3) use easily excreted or chemicallymodified CNTs that are readily degraded in vivo.

The promise of CNTs in photothermal cancer therapy still remains; realization of this potential will depend on production of well-characterized, biocompatible, homogeneous materials and well-designed efficacy and toxicology studies.

\section{Acknowledgments}

This work was supported in part by grants RO1CA12842 (SVT) from the National Cancer Institute/National Institutes of Health, W81XWH-10-1-0434 (SVT) from the Department of Defense, and by R00CA154006 (RS) from the National Cancer Institute/ National Institutes of Health. The content is solely the responsibility of the authors and does not necessarily represent the official views of the National Cancer Institute, the National Institutes of Health, or the Department of Defense.

\section{References}

1. Ebbesen TW. Carbon nanotubes. Physics Today. 1996; 49:26-32.

2. Sailor MJ, Park JH. Hybrid Nanoparticles for Detection and Treatment of Cancer. Advanced Materials. 2012; 24:3779-3802. [PubMed: 22610698]

3. Fisher C, Rider AE, Han ZJ, Kumar S, Levchenko I, Ostrikov K. Applications and Nanotoxicity of Carbon Nanotubes and Graphene in Biomedicine. Journal of Nanomaterials. 2012 Article ID 315185. 19 pages.

4. Gulati N, Gupte H. Two Faces of Carbon Nanotube: Toxicities and Pharmaceutical Applications. Critical Reviews in Therapeutic Drug Carrier Systems. 2012; 29:65-88. [PubMed: 22356722]

5. Harris DL, Bawa R. The carbon nanotube patent landscape in nanomedicine: an Expert opinion. Expert Opinion on Therapeutic Patents. 2007; 17:1165-1174.

6. Lacerda L, Bianco A, Prato M, Kostarelos K. Carbon nanotubes as nanomedicines: From toxicology to pharmacology. Advanced Drug Delivery Reviews. 2006; 58:1460-1470. [PubMed: 17113677]

7. Lacerda L, Bianco A, Prato M, Kostarelos K. Carbon nanotube cell translocation and delivery of nucleic acids in vitro and in vivo. Journal of Materials Chemistry. 2008; 18:17-22.

8. Lacerda L, Raffa S, Prato M, Bianco A, Kostarelos K. Cell-penetrating CNTs for delivery of therapeutics. Nano Today. 2007; 2:38-43. 
9. Lacerda L, Russier J, Pastorin G, Herrero MA, Venturelli E, Dumortier H, Al-Jamal KT, Prato M, Kostarelos K, Bianco A. Translocation mechanisms of chemically functionalised carbon nanotubes across plasma membranes. Biomaterials. 2012; 33:3334-3343. [PubMed: 22289266]

10. Bhirde AA, Patel S, Sousa AA, Patel V, Molinolo AA, Ji YM, Leapman RD, Gutkind JS, Rusling JF. Distribution and clearance of PEG-single-walled carbon nanotube cancer drug delivery vehicles in mice. Nanomedicine. 2010; 5:1535-1546. [PubMed: 21143032]

11. Singh R, Pantarotto D, McCarthy D, Chaloin O, Hoebeke J, Partidos CD, Briand JP, Prato M, Bianco A, Kostarelos K. Binding and condensation of plasmid DNA onto functionalized carbon nanotubes: Toward the construction of nanotube-based gene delivery vectors. Journal of the American Chemical Society. 2005; 127:4388-4396. [PubMed: 15783221]

12. Xue YD, Bao L, Xiao XR, Ding L, Lei JP, Ju HX. Noncovalent functionalization of carbon nanotubes with lectin for label-free dynamic monitoring of cell-surface glycan expression. Analytical Biochemistry. 2011; 410:92-97. [PubMed: 21094122]

13. Ananta JS, Matson ML, Tang AM, Mandal T, Lin S, Wong K, Wong ST, Wilson LJ. SingleWalled Carbon Nanotube Materials as T-2-Weighted MRI Contrast Agents. Journal of Physical Chemistry C. 2009; 113:19369-19372.

14. Bhirde AA, Sousa AA, Patel V, Azari AA, Gutkind JS, Leapman RD, Rusling JF. Imaging the distribution of individual platinum-based anticancer drug molecules attached to single-wall carbon nanotubes. Nanomedicine. 2009; 4:763-772. [PubMed: 19839812]

15. Adeli M, Hakimpoor F, Ashiri M, Kabiri R, Bavadi M. Anticancer drug delivery systems based on noncovalent interactions between carbon nanotubes and linear-dendritic copolymers. Soft Matter. 2011; 7:4062-4070.

16. Ali-Boucetta H, Al-Jamal KT, McCarthy D, Prato M, Bianco A, Kostarelos K. Multiwalled carbon nanotube-doxorubicin supramolecular complexes for cancer therapeutics. Chemical Communications. 2008:459-461. [PubMed: 18188467]

17. Al-Jamal KT, Toma FM, Yilmazer A, Ali-Boucetta H, Nunes A, Herrero MA, Tian BW, Eddaoui A, Al-Jamal WT, Bianco A, Prato M, Kostarelos K. Enhanced cellular internalization and gene silencing with a series of cationic dendron-multiwalled carbon nanotube:siRNA complexes. Faseb Journal. 2010; 24:4354-4365. [PubMed: 20647548]

18. Kostarelos K, Lacerda L, Partidos CD, Prato M, Blanco A. Carbon nanotube-mediated delivery of peptides and genes to cells: translating nanobiotechnology to therapeutics. Journal of Drug Delivery Science and Technology. 2005; 15:41-47.

19. Ruggiero A, Villa CH, Holland JP, Sprinkle SR, May C, Lewis JS, Scheinberg DA, McDevitt MR. Imaging and treating tumor vasculature with targeted radiolabeled carbon nanotubes. International Journal of Nanomedicine. 2010; 5:783-802. [PubMed: 21042424]

20. Sahoo NG, Bao HQ, Pan YZ, Pal M, Kakran M, Cheng HKF, Li L, Tan LP. Functionalized carbon nanomaterials as nanocarriers for loading and delivery of a poorly water-soluble anticancer drug: a comparative study. Chemical Communications. 2011; 47:5235-5237. [PubMed: 21451845]

21. de la Zerda A, Zavaleta C, Keren S, Vaithilingam S, Bodapati S, Liu Z, Levi J, Smith BR, Ma TJ, Oralkan O, Cheng Z, Chen XY, Dai HJ, Khuri-Yakub BT, Gambhir SS. Carbon nanotubes as photoacoustic molecular imaging agents in living mice. Nat Nanotechnol. 2008; 3:557-562. [PubMed: 18772918]

22. Ding XF, Singh R, Burke A, Hatcher H, Olson J, Kraft RA, Schmid M, Carroll D, Bourland JD, Akman S, Torti FM, Torti SV. Development of iron-containing multiwalled carbon nanotubes for MR-guided laser-induced thermotherapy. Nanomedicine. 2011; 6:1341-1352. [PubMed: 21506687]

23. Pantarotto D, Singh R, McCarthy D, Erhardt M, Briand JP, Prato M, Kostarelos K, Bianco A. Functionalized carbon nanotubes for plasmid DNA gene delivery. Angewandte ChemieInternational Edition. 2004; 43:5242-5246.

24. Shi DL. Integrated Multifunctional Nanosystems for Medical Diagnosis and Treatment. Advanced Functional Materials. 2009; 19:3356-3373.

25. Kostarelos K, Bianco A, Prato M. Promises, facts and challenges for carbon nanotubes in imaging and therapeutics. Nat Nanotechnol. 2009; 4:627-633. [PubMed: 19809452] 
26. Day ES, Morton JG, West JL. Nanoparticles for thermal cancer therapy. J Biomech Eng. 2009; 131:074001. [PubMed: 19640133]

27. Kam NW, O'Connell M, Wisdom JA, Dai H. Carbon nanotubes as multifunctional biological transporters and near-infrared agents for selective cancer cell destruction. P Natl Acad Sci USA. $2005 ; 102: 11600-11605$.

28. Burke A, Ding XF, Singh R, Kraft RA, Levi-Polyachenko N, Rylander MN, Szot C, Buchanan C, Whitney J, Fisher J, Hatcher HC, D'Agostino R, Kock ND, Ajayan PM, Carroll DL, Akman S, Torti FM, Torti SV. Long-term survival following a single treatment of kidney tumors with multiwalled carbon nanotubes and near-infrared radiation. P Natl Acad Sci USA. 2009; 106:12897-12902.

29. Yang K, Zhang S, Zhang G, Sun X, Lee ST, Liu Z. Graphene in mice: ultrahigh in vivo tumor uptake and efficient photothermal therapy. Nano lett. 2010; 10:3318-3323. [PubMed: 20684528]

30. Jordan A. Hyperthermia classic commentary: 'Inductive heating of ferrimagnetic particles and magnetic fluids: Physical evaluation of their potential for hyperthermia' by Andreas Jordan et al., International Journal of Hyperthermia, 1993;9:51-68. International Journal of Hyperthermia. 2009; 25:512-516. [PubMed: 19848613]

31. Dickerson EB, Dreaden EC, Huang X, El-Sayed IH, Chu H, Pushpanketh S, McDonald JF, ElSayed MA. Gold nanorod assisted near-infrared plasmonic photothermal therapy (PPTT) of squamous cell carcinoma in mice. Cancer Letters. 2008; 269:57-66. [PubMed: 18541363]

32. Hirsch LR, Stafford RJ, Bankson JA, Sershen SR, Rivera B, Price RE, Hazle JD, Halas NJ, West JL. Nanoshell-mediated near-infrared thermal therapy of tumors under magnetic resonance guidance. P Natl Acad Sci USA. 2003; 100:13549-13554.

33. O'Neal DP, Hirsch LR, Halas NJ, Payne JD, West JL. Photo-thermal tumor ablation in mice using near infrared-absorbing nanoparticles. Cancer Lett. 2004; 209:171-176. [PubMed: 15159019]

34. Emami B, Song CW. Physiological mechanisms in hyperthermia: a review. International Journal of Radiation Oncology, Biology, Physics. 1984; 10:289-295.

35. Fajardo LF, Egbert B, Marmor J, Hahn GM. Effects of hyperthermia in a malignant tumor. Cancer. 1980; 45:613-623. [PubMed: 7353209]

36. Coss RA, Dewey WC, Bamburg JR. Effects of hyperthermia on dividing Chinese hamster ovary cells and on microtubules in vitro. Cancer Res. 1982; 42:1059-1071. [PubMed: 7199378]

37. Roti JLR. Cellular responses to hyperthermia (40-46C): Cell killing and molecular events. International Journal of Hyperthermia. 2008; 24:3-15. [PubMed: 18214765]

38. Subjeck JR, Sciandra JJ, Chao CF, Johnson RJ. Heat shock proteins and biological response to hyperthermia. The British journal of cancer. 1982; 5:127-131. [PubMed: 6950747]

39. Nikfarjam M, Muralidharan V, Christophi C. Mechanisms of Focal Heat Destruction of Liver Tumors. Journal of Surgical Research. 2005; 127:208-223. [PubMed: 16083756]

40. Dewhirst MW, Prosnitz L, Thrall D, Prescott D, Clegg S, Charles C, MacFall J, Rosner G, Samulski T, Gillette E, LaRue S. Hyperthermic treatment of malignant diseases: current status and a view toward the future. Seminars in oncology. 1997; 24:616-625. [PubMed: 9422258]

41. Falk MH, Issels RD. Hyperthermia in oncology. International Journal of Hyperthermia. 2001; 17:1-18. [PubMed: 11212876]

42. Atkinson RL, Zhang M, Diagaradjane P, Peddibhotla S, Contreras A, Hilsenbeck SG, Woodward WA, Krishnan S, Chang JC, Rosen JM. Thermal enhancement with optically activated gold nanoshells sensitizes breast cancer stem cells to radiation therapy. Science Translational Medicine. 2011; 2:55ra-79.

43. Wust P, Hildebrandt B, Sreenivasa G, Rau B, Gellermann J, Riess H, Felix R, Schlag PM. Hyperthermia in combined treatment of cancer. The Lancet Oncology. 2002; 3:487-497. [PubMed: 12147435]

44. V R, Llovet Josep M, Brú Concepció, Bianchi Lluís, Salmeron Joan Manuel, Boix Loreto, Ganau Sergi, Sala Margarita, Pagès Mario, Ayuso Carmen, Solé Manel, Rodés Joan, Bruix Jordi. The Barcelona Clínic Liver Cancer Group. Increased risk of tumor seeding after percutaneous radiofrequency ablation for single hepatocellular carcinoma. Hepatology. 2001; 33:1124-1129. [PubMed: 11343240]

Adv Drug Deliv Rev. Author manuscript; available in PMC 2014 December 01. 
45. Baronzio G, Gramaglia A, Fiorentini G. Review. Current role and future perspectives of hyperthermia for prostate cancer treatment. In Vivo. 2009; 23:143-146. [PubMed: 19368139]

46. Krishnan S, Diagaradjane P, Cho SH. Nanoparticle-mediated thermal therapy: Evolving strategies for prostate cancer therapy. International Journal of Hyperthermia. 2010; 26:775-789. [PubMed: 20858069]

47. Silva AC, Oliveira TR, Mamani JB, Malheiros SM, Malavolta L, Pavon LF, Sibov TT, Amaro E Jr, Tannus A, Vidoto EL, Martins MJ, Santos RS, Gamarra LF. Application of hyperthermia induced by superparamagnetic iron oxide nanoparticles in glioma treatment. International Journal of Nanomedicine. 2011; 6:591-603. [PubMed: 21674016]

48. Maier-Hauff K, Ulrich F, Nestler D, Niehoff H, Wust P, Thiesen B, Orawa H, Budach V, Jordan A. Efficacy and safety of intratumoral thermotherapy using magnetic iron-oxide nanoparticles combined with external beam radiotherapy on patients with recurrent glioblastoma multiforme. Journal of Neuro-Oncology. 2011; 103:317-324. [PubMed: 20845061]

49. Iancu C, Mocan L. Advances in cancer therapy through the use of carbon nanotube-mediated targeted hyperthermia. International Journal of Nanomedicine. 2011; 6:1675-1684. [PubMed: 21904457]

50. Konig K. Multiphoton microscopy in life sciences. Journal of Microscopy. 2000; 200:83-104. [PubMed: 11106949]

51. Weissleder R. A clearer vision for in vivo imaging. Nature biotechnology. 2001; 19:316-317.

52. Torti SV, Byrne F, Whelan O, Levi N, Ucer B, Schmid M, Torti FM, Akman S, Liu J, Ajayan PM, Nalamasu O, Carroll DL. Thermal ablation therapeutics based on CNx multi-walled nanotubes. International Journal of Nanomedicine. 2007; 2:707-714. [PubMed: 18203437]

53. Robinson JT, Welsher K, Tabakman SM, Sherlock SP, Wang H, Luong R, Dai H. High Performance In Vivo Near-IR (>1 mum) Imaging and Photothermal Cancer Therapy with Carbon Nanotubes. Nano Research. 2010; 3:779-793. [PubMed: 21804931]

54. Gannon CJ, Cherukuri P, Yakobson BI, Cognet L, Kanzius JS, Kittrell C, Weisman RB, Pasquali M, Schmidt HK, Smalley RE, Curley SA. Carbon nanotube-enhanced thermal destruction of cancer cells in a noninvasive radiofrequency field. Cancer. 2007; 110:2654-2665. [PubMed: 17960610]

55. Muller S. Magnetic fluid hyperthermia therapy for malignant brain tumors-an ethical discussion. Nanomedicine-Nanotechnology Biology and Medicine. 2009; 5:387-393.

56. Kangasniemi M, McNichols RJ, Bankson JA, Gowda A, Price RE, Hazle JD. Thermal therapy of canine cerebral tumors using a $980 \mathrm{~nm}$ diode laser with MR temperature-sensitive imaging feedback. Lasers in surgery and medicine. 2004; 35:41-50. [PubMed: 15278927]

57. Chen WR, Korbelik M, Bartels KE, Liu H, Sun J, Nordquist RE. Enhancement of laser cancer treatment by a chitosan-derived immunoadjuvant. Photochemistry and Photobiology. 2005; 81:190-195. [PubMed: 15535737]

58. Gnyawali SC, Chen Y, Wu F, Bartels KE, Wicksted JP, Liu H, Sen CK, Chen WR. Temperature measurement on tissue surface during laser irradiation. Medical and Biological Engineering and Computing. 2008; 46:159-168. [PubMed: 17891430]

59. Huang N, Wang H, Zhao J, Lui H, Korbelik M, Zeng H. Single-wall carbon nanotubes assisted photothermal cancer therapy: Animal study with a murine model of squamous cell carcinoma. Lasers in surgery and medicine. 2010; 42:638-648. [PubMed: 20949599]

60. Moon HK, Lee SH, Choi HC. In Vivo Near-Infrared Mediated Tumor Destruction by Photothermal Effect of Carbon Nanotubes. Acs Nano. 2009; 3:3707-3713. [PubMed: 19877694]

61. Xie B, Singh R, Torti FM, Keblinski P, Torti S. Heat localization for targeted tumor treatment with nanoscale near-infrared radiation absorbers. Physics in Medicine and Biology. 2012; 57:57655775. [PubMed: 22948207]

62. Murakami T, Nakatsuji H, Inada M, Matoba Y, Umeyama T, Tsujimoto M, Isoda S, Hashida M, Imahori H. Photodynamic and Photothermal Effects of Semiconducting and Metallic-Enriched Single-Walled Carbon Nanotubes. Journal of the American Chemical Society. 2012; 134:1786217865. [PubMed: 23083004] 
63. Ghosh S, Dutta S, Gomes E, Carroll D, D'Agostino R Jr, Olson J, Guthold M, Gmeiner WH. Increased heating efficiency and selective thermal ablation of malignant tissue with DNA-encased multiwalled carbon nanotubes. Acs Nano. 2009; 3:2667-2673. [PubMed: 19655728]

64. Maeda H, Wu J, Sawa T, Matsumura Y, Hori K. Tumor vascular permeability and the EPR effect in macromolecular therapeutics: a review. Journal of Controlled Release. 2000; 65:271-284. [PubMed: 10699287]

65. Liu Z, Tabakman SM, Chen Z, Dai HJ. Preparation of carbon nanotube bioconjugates for biomedical applications. Nature Protocols. 2009; 4:1372-1382.

66. Cato MH, D'Annibale F, Mills DM, Cerignoli F, Dawson MI, Bergamaschi E, Bottini N, Magrini A, Bergamaschi A, Rosato N, Rickert RC, Mustelin T, Bottini M. Cell-type specific and cytoplasmic targeting of PEGylated carbon nanotube-based nanoassemblies. J Nanosci Nanotechno. 2008; 8:2259-2269.

67. Liu Z, Chen K, Davis C, Sherlock S, Cao QZ, Chen XY, Dai HJ. Drug delivery with carbon nanotubes for in vivo cancer treatment. Cancer Res. 2008; 68:6652-6660. [PubMed: 18701489]

68. Liu Z, Cai WB, He LN, Nakayama N, Chen K, Sun XM, Chen XY, Dai HJ. In vivo biodistribution and highly efficient tumour targeting of carbon nanotubes in mice. Nat Nanotechnol. 2007; 2:4752. [PubMed: 18654207]

69. Liu XW, Tao HQ, Yang K, Zhang SA, Lee ST, Liu ZA. Optimization of surface chemistry on single-walled carbon nanotubes for in vivo photothermal ablation of tumors. Biomaterials. 2011; 32:144-151. [PubMed: 20888630]

70. McDevitt MR, Chattopadhyay D, Kappel BJ, Jaggi JS, Schiffman SR, Antczak C, Njardarson JT, Brentjens R, Scheinberg DA. Tumor targeting with antibody-functionalized, radiolabeled carbon nanotubes. Journal of Nuclear Medicine. 2007; 48:1180-1189. [PubMed: 17607040]

71. Welsher K, Liu Z, Daranciang D, Dai H. Selective probing and imaging of cells with single walled carbon nanotubes as near-infrared fluorescent molecules. Nano lett. 2008; 8:586-590. [PubMed: 18197719]

72. Kamen BA, Smith AK. A review of folate receptor alpha cycling and 5-methyltetrahydrofolate accumulation with an emphasis on cell models in vitro. Adv Drug Deliv Rev. 2004; 56:10851097. [PubMed: 15094208]

73. Zhou F, Xing D, Ou Z, Wu B, Resasco DE, Chen WR. Cancer photothermal therapy in the nearinfrared region by using single-walled carbon nanotubes. Journal of Biomedical Optics. 2009; 14:021009. [PubMed: 19405722]

74. Kang B, Yu D, Dai Y, Chang S, Chen D, Ding Y. Cancer-Cell Targeting and Photoacoustic Therapy Using Carbon Nanotubes as "Bomb" Agents. Small. 2009; 5:1292-1301. [PubMed: 19274646]

75. Marches R, Mikoryak C, Wang RH, Pantano P, Draper RK, Vitetta ES. The importance of cellular internalization of antibody-targeted carbon nanotubes in the photothermal ablation of breast cancer cells. Nanotechnology. 2011; 22:095101. [PubMed: 21258147]

76. Xiao Y, Gao X, Taratula O, Treado S, Urbas A, Holbrook RD, Cavicchi RE, Avedisian CT, Mitra S, Savla R, Wagner PD, Srivastava S, He H. Anti-HER2 IgY antibody-functionalized singlewalled carbon nanotubes for detection and selective destruction of breast cancer cells. BMC Cancer. 2009; 9:351. [PubMed: 19799784]

77. Wang CH, Huang YJ, Chang CW, Hsu WM, Peng CA. In vitro photothermal destruction of neuroblastoma cells using carbon nanotubes conjugated with GD2 monoclonal antibody. Nanotechnology. 2009; 20:315101. [PubMed: 19597244]

78. Ning S, Lu S, Wickstrom E, Panchapakesan B. Integrated molecular targeting of IGF1R and HER2 surface receptors and destruction of breast cancer cells using single wall carbon nanotubes. Nanotechnology. 2007; 18:315101.

79. Mahon E, Salvati A, Bombelli FB, Lynch I, Dawson KA. Designing the nanoparticle-biomolecule interface for "targeting and therapeutic delivery". Journal of Controlled Release. 2012; 161:164174. [PubMed: 22516097]

80. Teeguarden JG, Hinderliter PM, Orr G, Thrall BD, Pounds JG. Particokinetics in vitro: Dosimetry considerations for in vitro nanoparticle toxicity assessments. Toxicological Sciences. 2007; 95:300-312. [PubMed: 17098817] 
81. Zhou FF, Xing D, Wu BY, Wu SN, Ou ZM, Chen WR. New Insights of Transmembranal Mechanism and Subcellular Localization of Noncovalently Modified Single-Walled Carbon Nanotubes. Nano lett. 2010; 10:1677-1681. [PubMed: 20369892]

82. Zhou FF, Wu SN, Wu BY, Chen WR, Xing D. Mitochondria-Targeting Single-Walled Carbon Nanotubes for Cancer Photothermal Therapy. Small. 2011; 7:2727-2735. [PubMed: 21861293]

83. Wang CH, Chiou SH, Chou CP, Chen YC, Huang YJ, Peng CA. Photothermolysis of glioblastoma stem-like cells targeted by carbon nanotubes conjugated with CD133 monoclonal antibody. Nanomedicine: Nanotechnology, Biology and Medicine. 2011; 7:69-79.

84. Burke AR, Singh RN, Carroll DL, Wood JCS, D'Agostino RB, Ajayan PM, Torti FM, Torti SV. The resistance of breast cancer stem cells to conventional hyperthermia and their sensitivity to nanoparticle-mediated photothermal therapy. Biomaterials. 2012; 33:2961-2970. [PubMed: 22245557]

85. Jordan CT, Guzman ML, Noble M. Cancer stem cells. New England Journal of Medicine. 2006; 355:1253-1261. [PubMed: 16990388]

86. Singh SK, Hawkins C, Clarke ID, Squire JA, Bayani J, Hide T, Henkelman RM, Cusimano MD, Dirks PB. Identification of human brain tumour initiating cells. Nature. 2004; 432:396-401. [PubMed: 15549107]

87. Zeppernick F, Ahmadi R, Campos B, Dictus C, Helmke BM, Becker N, Lichter P, Unterberg A, Radlwimmer B, Herold-Mende CC. Stem Cell Marker CD133 Affects Clinical Outcome in Glioma Patients. Clinical Cancer Research. 2008; 14:123-129. [PubMed: 18172261]

88. Beier D, Wischhusen J, Dietmaier W, Hau P, Proescholdt M, Brawanski A, Bogdahn U, Beier CP. CD133 Expression and Cancer Stem Cells Predict Prognosis in High-grade Oligodendroglial Tumors. Brain Pathology. 2008; 18:370-377. [PubMed: 18371181]

89. Bao S, Wu Q, McLendon RE, Hao Y, Shi Q, Hjelmeland AB, Dewhirst MW, Bigner DD, Rich JN. Glioma stem cells promote radioresistance by preferential activation of the DNA damage response. Nature. 2006; 444:756-760. [PubMed: 17051156]

90. Lee J, Kotliarova S, Kotliarov Y, Li A, Su Q, Donin NM, Pastorino S, Purow BW, Christopher N, Zhang W, Park JK, Fine HA. Tumor stem cells derived from glioblastomas cultured in bFGF and EGF more closely mirror the phenotype and genotype of primary tumors than do serum-cultured cell lines. Cancer Cell. 2006; 9:391-403. [PubMed: 16697959]

91. Galanzha EI, Kim JW, Zharov VP. Nanotechnology-based molecular photoacoustic and photothermal flow cytometry platform for in-vivo detection and killing of circulating cancer stem cells. Journal of biophotonics. 2009; 2:725-735. [PubMed: 19957272]

92. Al-Hajj M, Wicha MS, Benito-Hernandez A, Morrison SJ, Clarke MF. Prospective identification of tumorigenic breast cancer cells. P Natl Acad Sci USA. 2003; 100:3983-3988.

93. Sun X, Xiong Y, Chen P, Lin J, Ji W, Lim JH, Yang SS, Hagan DJ, Van Stryland EW. Investigation of an optical limiting mechanism in multiwalled carbon nanotubes. Applied optics. 2000; 39:1998-2001. [PubMed: 18345099]

94. Chakravarty P, Qian W, El-Sayed MA, Prausnitz MR. Delivery of molecules into cells using carbon nanoparticles activated by femtosecond laser pulses. Nat Nanotechnol. 2010; 5:607-611. [PubMed: 20639882]

95. Urban AS, Fedoruk M, Horton MR, Radler JO, Stefani FD, Feldmann J. Controlled nanometric phase transitions of phospholipid membranes by plasmonic heating of single gold nanoparticles. Nano lett. 2009; 9:2903-2908. [PubMed: 19719109]

96. Pommier Y, Sordet O, Antony S, Hayward RL, Kohn KW. Apoptosis defects and chemotherapy resistance: molecular interaction maps and networks. Oncogene. 2004; 23:2934-2949. [PubMed: 15077155]

97. Gottesman MM. Mechanisms of cancer drug resistance. Annual Review of Medicine. 2002; 53:615-627.

98. Fisher JW, Sarkar S, Buchanan CF, Szot CS, Whitney J, Hatcher HC, Torti SV, Rylander CG, Rylander MN. Photothermal response of human and murine cancer cells to multiwalled carbon nanotubes after laser irradiation. Cancer Res. 2010; 70:9855-9864. [PubMed: 21098701]

99. Kratz F. Albumin, a versatile carrier in oncology. Int J Clin Pharmacol Ther. 2010; 48:453-455. [PubMed: 20557842] 
100. Levi-Polyachenko NH, Merkel EJ, Jones BT, Carroll DL, Stewart JHt. Rapid photothermal intracellular drug delivery using multiwalled carbon nanotubes. Molecular Pharmaceutics. 2009; 6:1092-1099. [PubMed: 19545174]

101. Raffa V, Gherardini L, Vittorio O, Bardi G, Ziaei A, Pizzorusso T, Riggio C, Nitodas S, Karachalios T, Al-Jamal KT, Kostarelos K, Costa M, Cuschieri A. Carbon nanotube-mediated wireless cell permeabilization: drug and gene uptake. Nanomedicine (Lond). 2011; 6:1709-1718. [PubMed: 22122583]

102. Feazell RP, Nakayama-Ratchford N, Dai H, Lippard SJ. Soluble single-walled carbon nanotubes as longboat delivery systems for Platinum(IV) anticancer drug design. Journal of the American Chemical Society. 2007; 129:8438-8439. [PubMed: 17569542]

103. Wang L, Shi J, Jia X, Liu R, Wang H, Wang Z, Li L, Zhang J, Zhang C, Zhang Z. NIR-/pHResponsive Drug Delivery of Functionalized Single-Walled Carbon Nanotubes for Potential Application in Cancer Chemo-Photothermal Therapy. Pharmaceutical Research. 2013 Jun 14. Epub ahead of print.

104. Zhang M, Murakami T, Ajima K, Tsuchida K, Sandanayaka AS, Ito O, Iijima S, Yudasaka M. Fabrication of $\mathrm{ZnPc} /$ protein nanohorns for double photodynamic and hyperthermic cancer phototherapy. Proc Natl Acad Sci U S A. 2008; 105:14773-14778. [PubMed: 18815374]

105. Villa CH, Dao T, Ahearn I, Fehrenbacher N, Casey E, Rey DA, Korontsvit T, Zakhaleva V, Batt CA, Philips MR, Scheinberg DA. Single-Walled Carbon Nanotubes Deliver Peptide Antigen into Dendritic Cells and Enhance IgG Responses to Tumor-Associated Antigens. Acs Nano. 2011; 5:5300-5311. [PubMed: 21682329]

106. Zhou FF, Wu S, Song S, Chen WR, Resasco DE, Xing D. Antitumor immunologically modified carbon nanotubes for photothermal therapy. Biomaterials. 2012; 33:3235-3242. [PubMed: 22296829]

107. Kosuge H, Sherlock S, Kitagawa T, Dai HJ, McConnell MV. Carbon Nanotubes Enable Optical Ablation of Vascular Macrophages. Circulation. 2011; 124

108. Miyako E, Deguchi T, Nakajima Y, Yudasaka M, Hagihara Y, Horie M, Shichiri M, Higuchi Y, Yamashita F, Hashida M, Shigeri Y, Yoshida Y, Iijima S. Photothermic regulation of gene expression triggered by laser-induced carbon nanohorns. P Natl Acad Sci USA. 2012; 109:75237528.

109. Miyako E, Hosokawa C, Kojima M, Yudasaka M, Funahashi R, Oishi I, Hagihara Y, Shichiri M, Takashima M, Nishio K, Yoshida Y. A Photo-Thermal-Electrical Converter Based On Carbon Nanotubes for Bioelectronic Applications. Angewandte Chemie-International Edition. 2011; 50:12266-12270.

110. Jain RK, Stylianopoulos T. Delivering nanomedicine to solid tumors. Nature Reviews Clinical Oncology. 2010; 7:653-664.

111. Adamson C, Kanu OO, Mehta AI, Di C, Lin N, Mattox AK, Bigner DD. Glioblastoma multiforme: a review of where we have been and where we are going. Expert Opinions in Investigational Drugs. 2009; 18:1061-1083.

112. Jain KK. Use of nanoparticles for drug delivery in glioblastoma multiforme. Expert Review of Neurotherapeutics. 2007; 7:363-372. [PubMed: 17425491]

113. Kanu OO, Mehta A, Di C, Lin N, Bortoff K, Bigner DD, Yan H, Adamson DC. Glioblastoma multiforme: a review of therapeutic targets. Expert Opinion on Therapeutic Targets. 2009; 13:701-718. [PubMed: 19409033]

114. Lima FR, Kahn SA, Soletti RC, Biasoli D, Alves T, da Fonseca AC, Garcia C, Romao L, Brito J, Holanda-Afonso R, Faria J, Borges H, Moura-Neto V. Glioblastoma: Therapeutic challenges, what lies ahead. Biochimica et Biophysica Acta. 2012; 1826:338-349. [PubMed: 22677165]

115. Rozhkova EA. Nanoscale Materials for Tackling Brain Cancer: Recent Progress and Outlook. Advanced Materials. 2011; 23:H136-H150. [PubMed: 21506172]

116. Ferrari M. Frontiers in cancer nanomedicine: directing mass transport through biological barriers. Trends in Biotechnology. 2010; 28:181-188. [PubMed: 20079548]

117. Li SD, Huang L. Pharmacokinetics and biodistribution of nanoparticles. Molecular Pharmaceutics. 2008; 5:496-504. [PubMed: 18611037] 
118. Kostarelos K. Rational design and engineering of delivery systems for therapeutics: biomedical exercises in colloid and surface science. Advances in Colloid and Interface Science. 2003; 106:147-168. [PubMed: 14672846]

119. Smith BR, Kempen P, Bouley D, Xu A, Liu Z, Melosh N, Dai HJ, Sinclair R, Gambhir SS. Shape Matters: Intravital Microscopy Reveals Surprising Geometrical Dependence for Nanoparticles in Tumor Models of Extravasation. Nano lett. 2012; 12:3369-3377. [PubMed: 22650417]

120. Nance EA, Woodworth GF, Sailor KA, Shih TY, Xu QG, Swaminathan G, Xiang D, Eberhart C, Hanes J. A Dense Poly (Ethylene Glycol) Coating Improves Penetration of Large Polymeric Nanoparticles Within Brain Tissue. Science Translational Medicine. 2012; 4

121. Biddlestone-Thorpe L, Marchi N, Guo K, Ghosh C, Janigro D, Valerie K, Yang H. Nanomaterialmediated CNS delivery of diagnostic and therapeutic agents. Advanced Drug Delivery Reviews. 2012; 64:605-613. [PubMed: 22178615]

122. Sykova E, Nicholson C. Diffusion in brain extracellular space. Physiological Reviews. 2008; 88:1277-1340. [PubMed: 18923183]

123. Thorne RG, Nicholson C. In vivo diffusion analysis with quantum dots and dextrans predicts the width of brain extracellular space. P Natl Acad Sci USA. 2006; 103:5567-5572.

124. Fan ZH, Advani SG. Characterization of orientation state of carbon nanotubes in shear flow. Polymer. 2005; 46:5232-5240.

125. Fakhri N, MacKintosh FC, Lounis B, Cognet L, Pasquali M. Brownian Motion of Stiff Filaments in a Crowded Environment. Science. 2010; 330:1804-1807. [PubMed: 21205665]

126. Fatin-Rouge N, Starchev K, Buffle J. Size effects on diffusion processes within agarose gels. Biophysical Journal. 2004; 86:2710-2719. [PubMed: 15111390]

127. Pluen A, Netti PA, Jain RK, Berk DA. Diffusion of macromolecules in agarose gels: Comparison of linear and globular configurations. Biophysical Journal. 1999; 77:542-552. [PubMed: 10388779]

128. Stylianopoulos T, Poh MZ, Insin N, Bawendi MG, Fukumura D, Munn LL, Jain RK. Diffusion of Particles in the Extracellular Matrix: The Effect of Repulsive Electrostatic Interactions. Biophysical Journal. 2010; 99:1342-1349. [PubMed: 20816045]

129. Chen BD, Zhang H, Zhai CX, Du N, Sun C, Xue JW, Yang DR, Huang H, Zhang B, Xie QP, Wu YL. Carbon nanotube-based magnetic-fluorescent nanohybrids as highly efficient contrast agents for multimodal cellular imaging. Journal of Materials Chemistry. 2010; 20:9895-9902.

130. Hartman KB, Laus S, Bolskar RD, Muthupillai R, Helm L, Toth E, Merbach AE, Wilson LJ. Gadonanotubes as ultrasensitive $\mathrm{pH}$-smart probes for magnetic resonance imaging. Nano lett. 2008; 8:415-419. [PubMed: 18215084]

131. Richard C, Doan BT, Beloeil JC, Bessodes M, Toth E, Scherman D. Noncovalent functionalization of carbon nanotubes with amphiphilic Gd3+ chelates: Toward powerful T-1 and T-2 MRI contrast agents. Nano lett. 2008; 8:232-236. [PubMed: 18088153]

132. Yin M, Wang ML, Miao F, Ji YX, Tian Z, Shen HB, Jia NQ. Water-dispersible multiwalled carbon nanotube/iron oxide hybrids as contrast agents for cellular magnetic resonance imaging. Carbon. 2012; 50:2162-2170.

133. Singh R, Pantarotto D, Lacerda L, Pastorin G, Klumpp C, Prato M, Bianco A, Kostarelos K. Tissue biodistribution and blood clearance rates of intravenously administered carbon nanotube radiotracers. P Natl Acad Sci USA. 2006; 103:3357-3362.

134. Lacerda L, Soundararajan A, Singh R, Pastorin G, Al-Jamal KT, Turton J, Frederik P, Herrero MA, Bao SLA, Emfietzoglou D, Mather S, Phillips WT, Prato M, Bianco A, Goins B, Kostarelos K. Dynamic Imaging of functionalized multi-walled carbon nanotube systemic circulation and urinary excretion. Advanced Materials. 2008; 20:225-230.

135. Welsher K, Sherlock SP, Dai HJ. Deep-tissue anatomical imaging of mice using carbon nanotube fluorophores in the second near-infrared window. P Natl Acad Sci USA. 2011; 108:8943-8948.

136. Biris AS, Galanzha EI, Li ZR, Mahmood M, Xu Y, Zharov VP. In vivo Raman flow cytometry for real-time detection of carbon nanotube kinetics in lymph, blood, and tissues. Journal of Biomedical Optics. 2009; 14 
137. Hong GS, Lee JC, Robinson JT, Raaz U, Xie LM, Huang NF, Cooke JP, Dai HJ. Multifunctional in vivo vascular imaging using near-infrared II fluorescence. Nature Medicine. 2012; 18:18411846.

138. Xiang L, Yuan Y, Xing D, Ou Z, Yang S, Zhou F. Photoacoustic molecular imaging with antibody-functionalized single-walled carbon nanotubes for early diagnosis of tumor. Journal of Biomedical Optics. 2009; 14:021008-021007. [PubMed: 19405721]

139. Kim JW, Galanzha EI, Shashkov EV, Moon HM, Zharov VP. Golden carbon nanotubes as multimodal photoacoustic and photothermal high-contrast molecular agents. Nat Nanotechnol. 2009; 4:688-694. [PubMed: 19809462]

140. de la Zerda A, Kim JW, Galanzha EI, Gambhir SS, Zharov VP. Advanced contrast nanoagents for photoacoustic molecular imaging, cytometry, blood test and photothermal theranostics. Contrast Media \& Molecular Imaging. 2011; 6:346-369. [PubMed: 22025336]

141. Picou L, McMann C, Elzer PH, Enright FM, Biris AS, Boldor D. Spatio-temporal thermal kinetics of in situ MWCNT heating in biological tissues under NIR laser irradiation. Nanotechnology. 2010; 21:435101. [PubMed: 20876978]

142. Rieke V, Pauly KB. MR thermometry. Journal of Magnetic Resonance Imaging. 2008; 27:376390. [PubMed: 18219673]

143. Salvador-Morales C, Gao WW, Ghatalia P, Murshed F, Aizu W, Langer R, Farokhzad OC. Multifunctional nanoparticles for prostate cancer therapy. Expert Review of Anticancer Therapy. 2009; 9:211-221. [PubMed: 19192959]

144. Biris AS, Boldor D, Palmer J, Monroe WT, Mahmood M, Dervishi E, Xu Y, Li Z, Galanzha EI, Zharov VP. Nanophotothermolysis of multiple scattered cancer cells with carbon nanotubes guided by time-resolved infrared thermal imaging. Journal of Biomedical Optics. 2009; 14:021007. [PubMed: 19405720]

145. Anderson RR, Parrish JA. Selective photothermolysis: precise microsurgery by selective absorption of pulsed radiation. Science. 1983; 220:524-527. [PubMed: 6836297]

146. Vitetta ES, Marches R, Mikoryak C, Wang RH, Pantano P, Draper RK. The importance of cellular internalization of antibody-targeted carbon nanotubes in the photothermal ablation of breast cancer cells. Nanotechnology. 2011; 22:095101. [PubMed: 21258147]

147. Zharov VP, Galitovskaya EN, Johnson C, Kelly T. Synergistic enhancement of selective nanophotothermolysis with gold nanoclusters: Potential for cancer therapy. Lasers in Surgery and Medicine. 2005; 37:219-226. [PubMed: 16175635]

148. Keblinski P, Cahill DG, Bodapati A, Sullivan CR, Taton TA. Limits of localized heating by electromagnetically excited nanoparticles. J Appl Phys. 2006; 100:054305.

149. Sarkar S, Zimmermann K, Leng WN, Vikesland P, Zhang JF, Dorn H, Diller T, Rylander C, Rylander MN. Measurement of the Thermal Conductivity of Carbon Nanotube-Tissue Phantom Composites with the Hot Wire Probe Method. Annals of Biomedical Engineering. 2011; 39:1745-1758. [PubMed: 21360225]

150. Sarkar S, Rylander MN. Treatment Planning Model for Nanotube-Mediated Laser Cancer Therapy. Lasers in Surgery and Medicine. 2009; 41:5.

151. Sargent LM, Reynolds SH, Castranova V. Potential pulmonary effects of engineered carbon nanotubes: in vitro genotoxic effects. Nanotoxicology. 2010; 4:396-408. [PubMed: 20925447]

152. Huizar I, Malur A, Midgette YA, Kukoly C, Chen PY, Ke PC, Podila R, Rao AM, Wingard CJ, Dobbs L, Barna BP, Kavuru MS, Thomassen MJ. Novel Murine Model of Chronic Granulomatous Lung Inflammation Elicited by Carbon Nanotubes. American Journal of Respiratory Cell and Molecular Biology. 2011; 45:858-866. [PubMed: 21398620]

153. Kolosnjaj-Tabi J, Hartman KB, Boudjemaa S, Ananta JS, Morgant G, Szwarc H, Wilson LJ, Moussa F. In Vivo Behavior of Large Doses of Ultrashort and Full-Length Single-Walled Carbon Nanotubes after Oral and Intraperitoneal Administration to Swiss Mice. Acs Nano. 2010; 4:1481-1492. [PubMed: 20175510]

154. Nagai H, Toyokuni S. Differences and similarities between carbon nanotubes and asbestos fibers during mesothelial carcinogenesis: Shedding light on fiber entry mechanism. Cancer Science. 2012; 103:1378-1390. [PubMed: 22568550] 
155. Muller J, Delos M, Panin N, Rabolli V, Huaux F, Lison D. Absence of Carcinogenic Response to Multiwall Carbon Nanotubes in a 2-Year Bioassay in the Peritoneal Cavity of the Rat. Toxicological Sciences. 2009; 110:442-448. [PubMed: 19429663]

156. Osmond-McLeod MJ, Poland CA, Murphy F, Waddington L, Morris H, Hawkins SC, Clark S, Aitken R, McCall MJ, Donaldson K. Durability and inflammogenic impact of carbon nanotubes compared with asbestos fibres. Particle and Fibre Toxicology. 2011; 8

157. Nunes A, Bussy C, Gherardini L, Meneghetti M, Herrero MA, Bianco A, Prato M, Pizzorusso T, Al-Jamal KT, Kostarelos K. In vivo degradation of functionalized carbon nanotubes after stereotactic administration in the brain cortex. Nanomedicine. 2012; 7:1485-1494. [PubMed: 22712575]

158. Bianco A, Kostarelos K, Prato M. Making carbon nanotubes biocompatible and biodegradable. Chemical Communications. 2011; 47:10182-10188. [PubMed: 21776531]

159. Schipper ML, Nakayama-Ratchford N, Davis CR, Kam NW, Chu P, Liu Z, Sun X, Dai H, Gambhir SS. A pilot toxicology study of single-walled carbon nanotubes in a small sample of mice. Nat Nanotechnol. 2008; 3:216-221. [PubMed: 18654506]

160. Ali-Boucetta H, Nunes A, Sainz R, Herrero MA, Tian B, Prato M, Bianco A, Kostarelos K. Asbestos-like Pathogenicity of Long Carbon Nanotubes Alleviated by Chemical Functionalization. Angewandte Chemie International Edition. 2013; 52:2274-2278.

161. Murphy FA, Poland CA, Duffin R, Al-Jamal KT, Ali-Boucetta H, Nunes A, Byrne F, Prina-Mello A, Volkov Y, Li SP, Mather SJ, Bianco A, Prato M, MacNee W, Wallace WA, Kostarelos K, Donaldson K. Length-Dependent Retention of Carbon Nanotubes in the Pleural Space of Mice Initiates Sustained Inflammation and Progressive Fibrosis on the Parietal Pleura. American Journal of Pathology. 2011; 178:2587-2600. [PubMed: 21641383]

162. Liang F, Sadana AK, Peera A, Chattopadhyay J, Gu ZN, Hauge RH, Billups WE. A convenient route to functionalized carbon nanotubes. Nano lett. 2004; 4:1257-1260.

163. Takagi A, Hirose A, Nishimura T, Fukumori N, Ogata A, Ohashi N, Kitajima S, Kanno J. Induction of mesothelioma in p53+/- mouse by intraperitoneal application of multi-wall carbon nanotube. Journal of Toxicological Sciences. 2008; 33:105-116. [PubMed: 18303189]

164. Vakarelski IU, Brown SC, Higashitani K, Moudgil BM. Penetration of living cell membranes with fortified carbon nanotube tips. Langmuir. 2007; 23:10893-10896. [PubMed: 17894512]

165. Mayer A, Vadon M, Rinner B, Novak A, Wintersteiger R, Fröhlich E. The role of nanoparticle size in hemocompatibility. Toxicology. 2009; 258:139-147. [PubMed: 19428933]

166. Radomski A, Jurasz P, Alonso-Escolano D, Drews M, Morandi M, Malinski T, Radomski MW. Nanoparticle-induced platelet aggregation and vascular thrombosis. British Journal of Pharmacology. 2005; 146:882-893. [PubMed: 16158070]

167. Semberova J, De Paoli Lacerda SH, Simakova O, Holada K, Gelderman MP, Simak J. Carbon nanotubes activate blood platelets by inducing extracellular $\mathrm{Ca} 2+$ influx sensitive to calcium entry inhibitors. Nano lett. 2009; 9:3312-3317. [PubMed: 19736974]

168. Dobrovolskaia MA, Aggarwal P, Hall JB, McNeil SE. Preclinical studies to understand nanoparticle interaction with the immune system and its potential effects on nanoparticle biodistribution. Molecular Pharmaceutics. 2008; 5:487-495. [PubMed: 18510338]

169. Deng XY, Wu F, Liu Z, Luo M, Li L, Ni QS, Jiao Z, Wu MH, Liu YF. The splenic toxicity of water soluble multi-walled carbon nanotubes in mice. Carbon. 2009; 47:1421-1428.

170. Qu GB, Bai YH, Zhang Y, Jia Q, Zhang WD, Yan B. The effect of multiwalled carbon nanotube agglomeration on their accumulation in and damage to organs in mice. Carbon. 2009; 47:20602069.

171. Yang ST, Wang X, Jia G, Gu YQ, Wang TC, Nie HY, Ge CC, Wang HF, Liu YF. Long-term accumulation and low toxicity of single-walled carbon nanotubes in intravenously exposed mice. Toxicology Letters. 2008; 181:182-189. [PubMed: 18760340]

172. Lacerda SH, Semberova J, Holada K, Simakova O, Hudson SD, Simak J. Carbon nanotubes activate store-operated calcium entry in human blood platelets. Acs Nano. 2011; 5:5808-5813. [PubMed: 21639133] 
173. Burke AR, Singh RN, Carroll DL, Owen JD, Kock ND, D'Agostino R Jr, Torti FM, Torti SV. Determinants of the thrombogenic potential of multiwalled carbon nanotubes. Biomaterials. 2011; 32:5970-5978. [PubMed: 21663954]

174. Meng J, Cheng XL, Liu J, Zhang WQ, Li XJ, Kong H, Xu HY. Effects of Long and Short Carboxylated or Aminated Multiwalled Carbon Nanotubes on Blood Coagulation. Plos One. 2012; 7

175. Cherukuri P, Gannon CJ, Leeuw TK, Schmidt HK, Smalley RE, Curley SA, Weisman RB. Mammalian pharmacokinetics of carbon nanotubes using intrinsic near-infrared fluorescence. $P$ Natl Acad Sci USA. 2006; 103:18882-18886.

176. Liu Z, Davis C, Cai WB, He L, Chen XY, Dai HJ. Circulation and long-term fate of functionalized biocompatible single-walled carbon nanotubes in mice probed by Raman spectroscopy. P Natl Acad Sci USA. 2008; 105:1410-1415.

177. Al-Jamal KT, Nunes A, Methven L, Ali-Boucetta H, Li SP, Toma FM, Herrero MA, Al-Jamal WT, ten Eikelder HMM, Foster J, Mather S, Prato M, Bianco A, Kostarelos K. Degree of Chemical Functionalization of Carbon Nanotubes Determines Tissue Distribution and Excretion Profile. Angewandte Chemie-International Edition. 2012; 51:6389-6393.

178. Lacerda L, Ali-Boucettal H, Herrero MA, Pastorin G, Bianco A, Prato M, Kostarelos K. Tissue histology and physiology following intravenous administration of different types of functionalized multiwalled carbon nanotubes. Nanomedicine. 2008; 3:149-161. [PubMed: 18373422]

179. Lacerda L, Herrero MA, Venner K, Bianco A, Prato M, Kostarelos K. Carbon-nanotube shape and individualization critical for renal excretion. Small. 2008; 4:1130-1132. [PubMed: 18666166]

180. Longmire M, Choyke PL, Kobayashi H. Clearance properties of nano-sized particles and molecules as imaging agents: considerations and caveats. Nanomedicine. 2008; 3:703-717. [PubMed: 18817471]

181. Ruggiero A, Villa CH, Bander E, Rey DA, Bergkvist M, Batt CA, Manova-Todorova K, Deen WM, Scheinberg DA, McDevitt MR. Paradoxical glomerular filtration of carbon nanotubes. P Natl Acad Sci USA. 2010; 107:12369-12374.

182. Deen WM, Lazzara MJ, Myers BD. Structural determinants of glomerular permeability. American Journal of Physiology-Renal Physiology. 2001; 281:F579-F596. [PubMed: 11553505]

183. Bussy C, Ali-Boucetta H, Kostarelos K. Safety Considerations for Graphene: Lessons Learnt from Carbon Nanotubes. Accounts of Chemical Research. 2013; 46:692-701. [PubMed: 23163827]

184. Markovic ZM, Harhaji-Trajkovic LM, Todorovic-Markovic BM, Kepic DP, Arsikin KM, Jovanovic SP, Pantovic AC, Dramicanin MD, Trajkovic VS. In vitro comparison of the photothermal anticancer activity of graphene nanoparticles and carbon nanotubes. Biomaterials. 2011; 32:1121-1129. [PubMed: 21071083]

185. Panchapakesan B, Lu S, Sivakumar K, Taker K, Cesarone G, Wickstrom E. Single-wall carbon nanotube nanobomb agents for killing breast cancer cells. NanoBioTechnology. 2005; 1:133139.

186. Burlaka A, Lukin S, Prylutska S, Remeniak O, Prylutskyy Y, Shuba M, Maksimenko S, Ritter U, Scharff P. Hyperthermic effect of multi-walled carbon nanotubes stimulated with near infrared irradiation for anticancer therapy: in vitro studies. 2010; 32:48-50.

Adv Drug Deliv Rev. Author manuscript; available in PMC 2014 December 01. 
A.

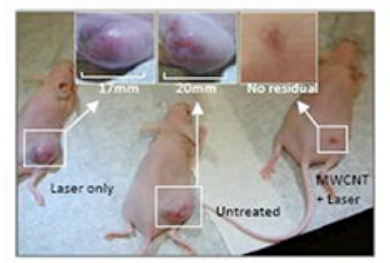

B.

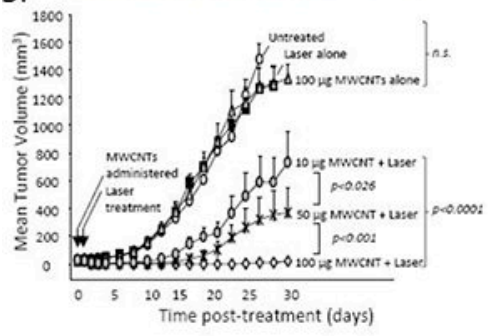

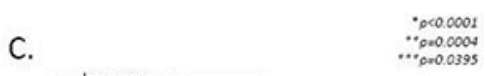

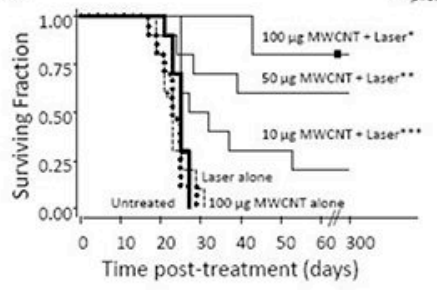

Figure 1.

Treatment of tumor bearing mice by CNMTT reduces tumor growth and increases long term survival. Nu/nu mice were implanted s.c. with RENCA tumors and divided into groups of 10. Mice were either left untreated, treated with MWCNT alone, treated with laser alone, or treated with the combination of MWCNT and laser ( $\left.3 \mathrm{~W} / \mathrm{cm}^{2} ; 30 \mathrm{~s}\right)$. (A) Photographs at day 21 post-treatment of representative mice from groups treated with laser only, untreated controls, or mice treated with $100 \mu \mathrm{g}$ of MWCNT plus laser. (B) Mice treated with the combination of MWCNTs and laser were injected with a range of MWCNT doses. Tumor sizes were measured every 2 days. Means and standard errors are shown. Control groups (untreated, treated with MWCNTs alone, or treated with laser alone) were statistically identical. There is a dose-dependent attenuation in tumor growth after $30 \mathrm{~s}$ of NIR laser treatment of MWCNT-loaded tumors ( $\mathrm{P}<0.0001$ ). (C) MWCNT-based photothermal therapy increases long-term survival of tumor-bearing mice. Survival of mice treated as described in (C) was assessed for 10 months after treatment. Kaplan-Meier curves demonstrate a significant increase in survival in mice treated with all doses of MWCNTs plus laser ( $\mathrm{P}<0.0001$ vs all controls). Survival curves for control groups were statistically identical $(\mathrm{P}>0.775)$. Adapted and reproduced with permission from Burke et al. PNAS 106 (2009) 12897-12902. 
CONVENTIONAL HEAT (WATER BATH): Stem cells are resistant

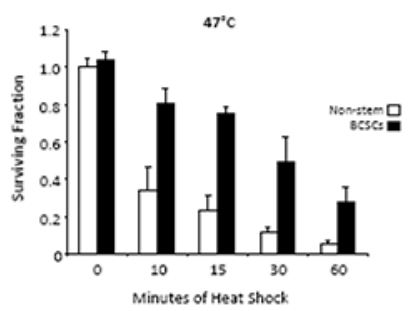

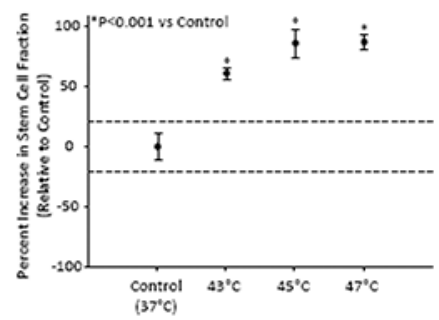

NANOTUBE-MEDIATED THERMAL THERAPY: Stem cells are sensitive

C.

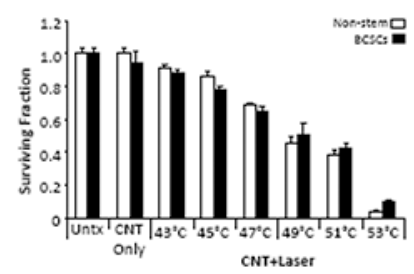

D.

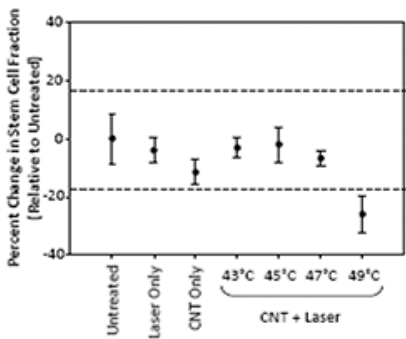

Figure 2.

Breast cancer stem cells are resistant to conventional hyperthermic cell death but sensitive to CNMTT. (A) Relative viability of cancer cells $24 \mathrm{~h}$ after water bath heat treatment as a model of conventional hyperthermia. Stem cell-like breast cancer cells (BCSCs) or bulk breast cancer (non-stem) cells were heated in a water bath at $47^{\circ} \mathrm{C}$ for $0-60 \mathrm{~min}$. MTT absorbance values were normalized to the untreated condition (" 0 " minutes heat shock). The results clearly show that BSCC subpopulations are more resistant to heat than breast cancer cells as a whole. (B) Sub-lethal hyperthermia enriches for the BCSC phenotype in bulk breast cancer cells. Changes in the CD $44^{\text {high}} / \mathrm{CD} 24^{\text {low }}$ stem cell fraction of surviving bulk breast cancer cells $24 \mathrm{~h}$ after water bath heat shock at $43^{\circ} \mathrm{C}, 45^{\circ} \mathrm{C}$ or $47^{\circ} \mathrm{C}$ were determined by flow cytometry. Shown are mean percent changes in the CD $44^{\text {high}} / \mathrm{CD} 24^{\text {low }}$ cell fraction normalized to the Untreated condition (which is set as 1.0 , i.e. " 0 percent change"). Dashed lines indicate the $95 \%$ C.I. for the Untreated condition. All heat treatments led to significant increases in the stem cell fraction $(\mathrm{p}<0.0001)$ relative to Untreated. $(\mathrm{C})$ In contrast, of BCSC and non-stem breast cancer cells are equally sensitive to CNMTT. Cancer cells were heat treated to specific temperatures by the combination of MWCNTs and NIR laser irradiation and the relative viability of BCSC and non-stem breast cancer cells was determined by MTT $24 \mathrm{~h}$ later and normalized to the "Untreated" conditions. "CNT Only" describes samples that were mixed with MWCNTs but were not laser treated. "CNT+ Laser" describes samples that were heat shocked to the indicated final temperatures by the combination of $50 \mathrm{mg} / \mathrm{mL}$ MWCNTs and $3 \mathrm{~W}$ laser radiation. In contrast to the water bath heating results, no significant difference between the sensitivity of stem-like and non-stem breast cancer cells was observed, and (D) no enrichment of the stem cell phenotype (quantified as in (B)) in viable cells $24 \mathrm{~h}$ after CNMTT was detected. Adapted and reproduced with permission from Burke et al. Biomaterials 33 (2012) 2961-2970. 


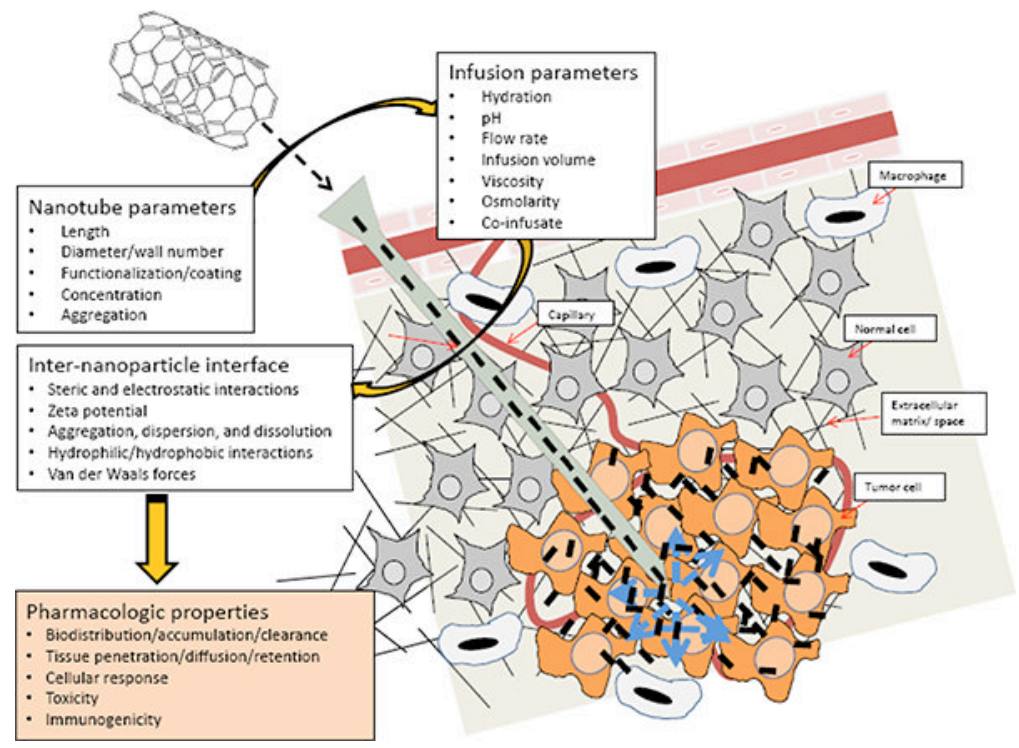

Figure 3.

Effective delivery of CNTs to the tumor is a central challenge for using CNTs to treat cancer. . In spite of the dynamic growth of innovative nanoplatforms, the path from bench to bedside is still challenging. Barriers within the tumor microenvironment, including vascular heterogeneity, extracellar matrix pore size, high interstitial pressure, and immune cell infiltration, limit the uniform penetration of nanotherapeutics, lead to inefficient delivery and reduce the potential efficacy of many treatments. Currently, there is an insufficient understanding of how CNTs interact with the tumor microenvironment. As shown here, there is a patchwork of inter-related properties that are dependent not just on the characteristics of the nanoparticle, but also upon the environment in which the particle is to be used and the strategy by which it will be delivered. These properties influence the pharmacologic behavior of the CNTs in vitro and in vivo. Failure to appropriately characterize CNTs has led to a bottleneck in their clinical translation due to inadequately designed studies at the pre-clinical level that could bridge cell- culture-to-rodent-to-human studies. Identification of CNT physicochemical and surface characteristics under specific infusion parameters and consideration of how the pathophysiology and anatomy of the target site influence the pharmacologic properties of CNTs will be necessary for the development of pharmaceutical grade material for clinical use. 

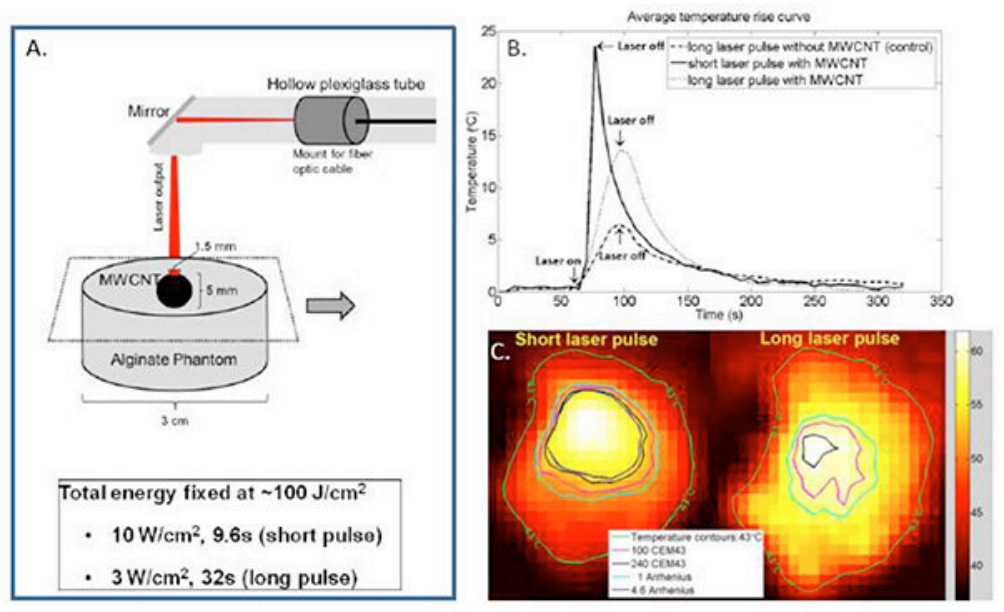

Figure 4.

MR thermography combined with damage modeling algorithms can be used to optimize the delivery of therapeutic heat to tumor targets. (A) Schematic of experimental design. The entire set-up was placed within the magnet of a 7T MRI. A YAG laser tuned to $1064 \mathrm{~nm}$ served as the laser source and the phantom was exposed to a total fixed radiant energy of approximately $100 \mathrm{~J} / \mathrm{cm}^{2}$ using either a high power, short duration pulse $\left(10 \mathrm{~W} / \mathrm{cm}^{2} ; 9.6 \mathrm{~s}\right.$; refered to as the "short pulse") or a low power, longer duration pulse $\left(3 \mathrm{~W} / \mathrm{cm}^{2} ; 32 \mathrm{~s}\right.$; referred to as the "long pulse"). (B) Time evolution of the average temperature measured by MR thermometry achieved in the MWCNT inclusion: Temperature increased approximately linearly with time in response to both long and short pulse irradiation with a rate of average temperature increase of 1.89 and $0.38{ }^{\circ} \mathrm{C} \mathrm{s}^{-1}$ and for the short and long pulse heating, respectively. Notably, the ratio of these heating rates is about 5 and is significantly greater than the ratio of heating powers (3.3), suggesting more heat diffuses away from the heated region during long pulse heating. (C) Temperature maps calculated by PRF MR thermometry of a coronal slice across the MWCNT inclusion and surrounding nanotube-free phantom generated at the time the laser was turned off. A temperature contour for which the peak temperature reached $43{ }^{\circ} \mathrm{C}$ (green curve) is shown. The images clearly show that heat is more localized following the short pulse treatment. Thermal damage contours calculated for 100 or 200 cumulative equivalent minutes at $43^{\circ} \mathrm{C}$ (100CEM43 (pink curve) and the 240CEM43 thresholds (blue curve)) and contours calculated using the Arrhenius damage integral are shown. Thermal necrosis is predicted to begin when the Arrhenius integral equals 1 (light blue curve), which is roughly equivalent to 100CEM43. Ninety-nine percent of cells are predicted to die when the Arrhenius integral equals 4.6 (dark blue curve), which is roughly equivalent to $240 \mathrm{CEM} 43$. Note that $99 \%$ cell death as calculated by the Arrhenius damage integral was not achieved using long laser pulse heating. Thus, for a fixed radiant exposure, short pulse heating of CNTs leads to a higher maximum temperature, a more rapid rate of temperature increase, more localized heating, and greater therapeutic efficacy. Adapted and reproduced with permission from Xie et al. Phys. Med. Biol. 57 (2012) 5765-75. 


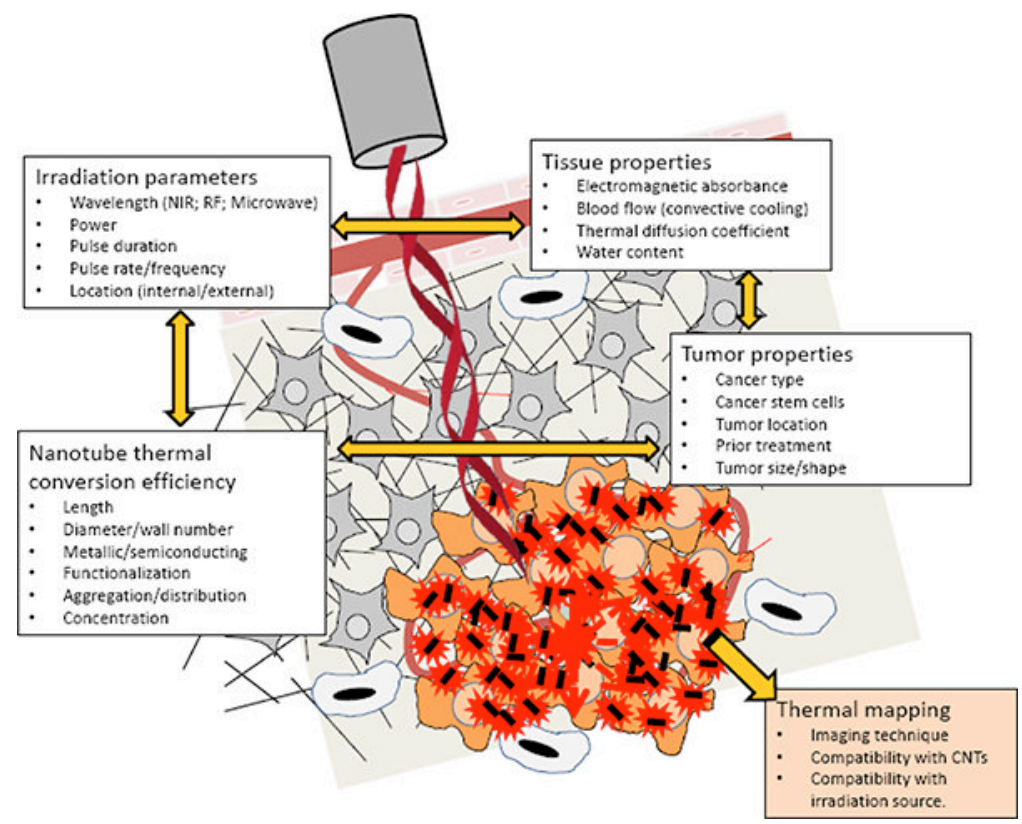

Figure 5.

Summary of important parameters which must be assessed for successful clinical translation of CNMTT. To maximize treatment efficacy and minimize collateral damage due to heat spread, laser irradiation parameters (irradiance, duration, duty cycle) must be carefully matched to the NIR absorptive characteristics and distribution of the CNTs as well as the thermal properties of the targeted and surrounding tissue. These parameters are highly interrelated and must be balanced with the underlying biology and biophysics of the tumor target. An understanding of both the NIR absorptive and thermal dispersive qualities of the tumor target is needed. Specific issues related to the sensitivity of the tumor and surrounding tissue to thermal ablation must be identified. Treatment should be compatible with a noninvasive thermal mapping modality (such as proton resonance frequency shift magnetic resonance (MR) thermography) to monitor temperature localization. 
Table 1

Preclinical assessment of CNMTT in cancer models

\begin{tabular}{|c|c|c|c|c|}
\hline Cancer Type & Experimental model & Material (effective dose) & $\begin{array}{l}\text { Laser (wavelength; radiant } \\
\text { exposure) }\end{array}$ & Reference \\
\hline \multirow{4}{*}{ Brain (human) } & $\begin{array}{l}\text { in vitro; adherent primary } \\
\text { glioblastoma cells }\end{array}$ & $\begin{array}{l}\text { SWCNT }(2.5 \mu \mathrm{g} / \text { well of } 24 \\
\text { well plate) }\end{array}$ & $808 \mathrm{~nm} ; 600 \mathrm{~J} / \mathrm{cm}^{2}$ & [83] \\
\hline & $\begin{array}{l}\text { in vitro; non-adherent U251 } \\
\text { glioblastoma cells }\end{array}$ & SWCNT $(10 \mu \mathrm{g} / \mathrm{ml})$ & $808 \mathrm{~nm} ; 600 \mathrm{~J} / \mathrm{cm}^{2}$ & [184] \\
\hline & $\begin{array}{l}\text { in vitro; non-adherent MDA- } \\
\text { MB-231 cells }\end{array}$ & $\begin{array}{l}\text { gold coated SWCNTs } \\
\text { (estimated } 0.5-1 \times 10^{4} \\
\text { SWCNTs per cell) }\end{array}$ & $850 \mathrm{~nm} ; 0.5 \mathrm{~J} / \mathrm{cm}^{2}$ & [91] \\
\hline & $\begin{array}{l}\text { in vivo murine flank tumor; } \\
\text { primary glioblastoma cells }\end{array}$ & MWCNT (10 $\mu \mathrm{g}$ - ex vivo) & $808 \mathrm{~nm} ; 600 \mathrm{~J} / \mathrm{cm}^{2}$ & [83] \\
\hline \multirow{7}{*}{ Breast (human) } & $\begin{array}{l}\text { in vitro; transformed human } \\
\text { mammary epithelial cells }\end{array}$ & MWCNT $(50 \mu \mathrm{g} / \mathrm{mL})$ & $1064 \mathrm{~nm} ; 90 \mathrm{~J} / \mathrm{cm}^{2}$ & [84] \\
\hline & in vitro; adherent BT- 474 cells & SWCNT $(5-10 \mu \mathrm{g} / \mathrm{ml})$ & $808 \mathrm{~nm} ; 5130 \mathrm{~J} / \mathrm{cm}^{2}$ & [75] \\
\hline & in vitro; adherent SK-BR-3 cells & SWCNT (4 $\mu \mathrm{g} / \mathrm{ml})$ & $808 \mathrm{~nm} ; 900 \mathrm{~J} / \mathrm{cm}^{2}$ & [76] \\
\hline & $\begin{array}{l}\text { in vitro; non-adherent BT474 } \\
\text { cells }\end{array}$ & SWCNT $(100 \mu \mathrm{g} / \mathrm{ml})$ & $800 \mathrm{~nm} ; 12 \mathrm{~J} / \mathrm{cm}^{2}$ & [185] \\
\hline & $\begin{array}{l}\text { in vitro; non-adherent MCF-7 } \\
\text { cells }\end{array}$ & SWCNT (not reported) & $808 \mathrm{~nm} ; 144 \mathrm{~J} / \mathrm{cm}^{2}$ & [78] \\
\hline & $\begin{array}{l}\text { in vivo murine flank tumor; } \\
\text { MDA-MB-231 cells }\end{array}$ & MWCNT $(100 \mu \mathrm{g}$ IT $)$ & $1064 \mathrm{~nm} ; 90 \mathrm{~J} / \mathrm{cm}^{2}$ & [22] \\
\hline & $\begin{array}{l}\text { in vivo murine flank tumor; } \\
\text { transformed human mammary } \\
\text { epithelial cells }\end{array}$ & MWCNT $(100 \mu \mathrm{g}$ IT) & $1064 \mathrm{~nm} ; 90 \mathrm{~J} / \mathrm{cm}^{2}$ & [84] \\
\hline \multirow{6}{*}{ Breast (murine) } & in vitro; adherent EMT6 cells & SWCNT $(3.5 \mu \mathrm{g} / \mathrm{ml})$ & $980 \mathrm{~nm} ; 120 \mathrm{~J} / \mathrm{cm}^{2}$ & [82] \\
\hline & in vitro; adherent EMT6 cells & SWCNT $(50 \mu \mathrm{g} / \mathrm{ml})$ & $980 \mathrm{~nm} ; 60-150 \mathrm{~J} / \mathrm{cm}^{2}$ & {$[106]$} \\
\hline & $\begin{array}{l}\text { in vivo murine flank tumor; } 4 \mathrm{~T} 1 \\
\text { cells }\end{array}$ & SWCNT $(70 \mu \mathrm{g}$ IV) & $808 \mathrm{~nm} ; 180 \mathrm{~J} / \mathrm{cm}^{2}$ & [53] \\
\hline & $\begin{array}{l}\text { in vivo murine flank tumor; } 4 \mathrm{~T} 1 \\
\text { cells }\end{array}$ & 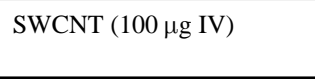 & $808 \mathrm{~nm} ; 300 \mathrm{~J} / \mathrm{cm}^{2}$ & [69] \\
\hline & $\begin{array}{l}\text { in vivo murine flank tumor; } \\
\text { EMT6 cells }\end{array}$ & 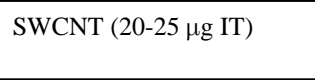 & $980 \mathrm{~nm} ; 300 \mathrm{~J} / \mathrm{cm}^{2}$ & [73] \\
\hline & $\begin{array}{l}\text { in vivo murine flank tumor; } \\
\text { EMT6 cells }\end{array}$ & SWCNT (1 mg IT) & $980 \mathrm{~nm} ; 450 \mathrm{~J} / \mathrm{cm}^{2}$ & [82] \\
\hline \multirow{2}{*}{ Cervical (human) } & in vitro; adherent Hela cells & MWCNT $(10 \mu \mathrm{g} / \mathrm{ml})$ & $1064 \mathrm{~nm} ; 128 \mathrm{~J} / \mathrm{cm}^{2}$ & [144] \\
\hline & in vitro; non-adherent HeLa cells & SWCNT $(25 \mu \mathrm{g} / \mathrm{ml})$ & $808 \mathrm{~nm} ; 168 \mathrm{~J} / \mathrm{cm}^{2}$ & [27] \\
\hline Erlich ascites (murine) & $\begin{array}{l}\text { in vitro; non-adherent Erlich } \\
\text { ascitic carcinoma cells }\end{array}$ & MWCNT $(100 \mu \mathrm{g} / \mathrm{ml})$ & $780-1400 \mathrm{~nm} ; 315 \mathrm{~J} / \mathrm{cm} 2$ & [186] \\
\hline Kidney (human) & in vitro; adherent CRL 1932 cells & $\begin{array}{l}\text { Nitrogen-doped MWCNT } \\
\text { (approx. } 83 \mu \mathrm{g} / \mathrm{ml} \text { ) }\end{array}$ & $1064 \mathrm{~nm} ; 720 \mathrm{~J} / \mathrm{cm}^{2}$ & [52] \\
\hline \multirow{3}{*}{ Kidney (murine) } & $\begin{array}{l}\text { in vitro; non-adherent RENCA } \\
\text { cells }\end{array}$ & MWCNT $(100 \mu \mathrm{g} / \mathrm{ml})$ & $1064 \mathrm{~nm} ; 135 \mathrm{~J} / \mathrm{cm}^{2}$ & [28] \\
\hline & $\begin{array}{l}\text { in vitro; non-adherent RENCA } \\
\text { cells }\end{array}$ & MWCNT $(100 \mu \mathrm{g} / \mathrm{ml})$ & $1064 \mathrm{~nm} ; 4590 \mathrm{~J} / \mathrm{cm}^{2}$ & [98] \\
\hline & $\begin{array}{l}\text { in vivo murine flank tumor; } \\
\text { RENCA cells }\end{array}$ & MWCNT $(100 \mu \mathrm{g}$ IT $)$ & $1064 \mathrm{~nm} ; 90 \mathrm{~J} / \mathrm{cm}^{2}$ & [28] \\
\hline Liver (human) & $\begin{array}{l}\text { in vitro; adherent HepG } 2 \text { or CRL } \\
4020 \text { cells }\end{array}$ & MWCNT $(1-50 \mu \mathrm{g} / \mathrm{ml})$ & $808 \mathrm{~nm} ; 7680 \mathrm{~J} / \mathrm{cm}^{2}$ & [49] \\
\hline
\end{tabular}




\begin{tabular}{|c|c|c|c|c|}
\hline Cancer Type & Experimental model & Material (effective dose) & $\begin{array}{l}\text { Laser (wavelength; radiant } \\
\text { exposure) }\end{array}$ & Reference \\
\hline & in vitro; adherent SK-BR-3 cells & SWCNT $(20 \mu \mathrm{g} / \mathrm{ml})$ & $1064 \mathrm{~nm} ; 4 \mathrm{~J} / \mathrm{cm}^{2}$ & [74] \\
\hline Lymph (human) & $\begin{array}{l}\text { in vitro; non-adherent Daudi } \\
\text { Burkitt's lymphoma cells }\end{array}$ & SWCNT $(90 \mu \mathrm{g} / \mathrm{ml})$ & $808 \mathrm{~nm} ; 2100 \mathrm{~J} / \mathrm{cm}^{2}$ & [94] \\
\hline Mouth (human) & $\begin{array}{l}\text { in vivo murine flank tumor; KB } \\
\text { epidermoid mouth carcinoma } \\
\text { cells }\end{array}$ & SWCNT $(12 \mu \mathrm{g}$ IT $)$ & $808 \mathrm{~nm} ; 684 \mathrm{~J} / \mathrm{cm}^{2}$ & [60] \\
\hline Neuroend ocrine (human) & $\begin{array}{l}\text { in vitro; adherent stNB-V1 } \\
\text { neuroblastoma cells }\end{array}$ & MWCNT $(5-10 \mu \mathrm{g} / \mathrm{ml})$ & $808 \mathrm{~nm} ; 3000 \mathrm{~J} / \mathrm{cm}^{2}$ & [77] \\
\hline \multirow[t]{2}{*}{ Prostate (human) } & in vitro; non-adherent PC-3 cells & MWCNT $(100 \mu \mathrm{g} / \mathrm{ml})$ & $1064 \mathrm{~nm} ; 4590 \mathrm{~J} / \mathrm{cm}^{2}$ & [98] \\
\hline & $\begin{array}{l}\text { in vivo murine flank tumor; PC-3 } \\
\text { cells }\end{array}$ & MWCNT $(50 \mu \mathrm{g}$ IT $)$ & $1064 \mathrm{~nm} ; 175 \mathrm{~J} / \mathrm{cm}^{2}$ & [63] \\
\hline Skin (murine) & $\begin{array}{l}\text { in vivo murine flank tumor; } \\
\text { SCCVII squamous carcinoma } \\
\text { cells }\end{array}$ & SWCNT $(60-100 \mu \mathrm{g}$ IT) & $785 \mathrm{~nm} ; 120 \mathrm{~J} / \mathrm{cm}^{2}$ & [59] \\
\hline
\end{tabular}

IT = intratumoral injection; IV = intravenous injection 